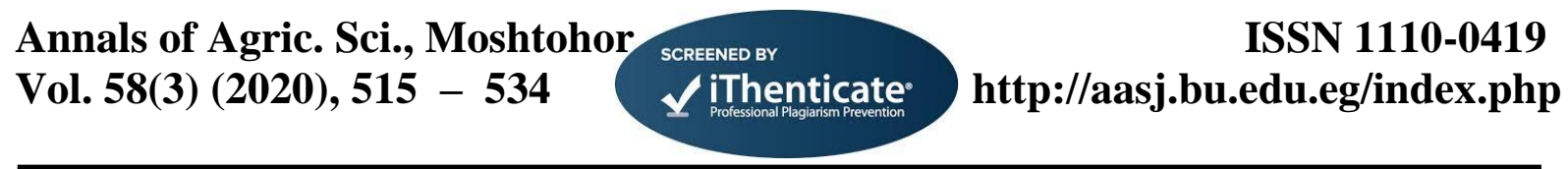

\title{
Effect of Water Stress, Nitrogen and Potassium Fertilizers on Maize Yield Productivity
}

\author{
El-Saeed M. M. El-Gedwy, Haroun M. M. El-Naggar, Nasser Kh. B. El-Gizawy and Haitham S. A. \\ Mansour \\ Agronomy Department, Faculty of Agriculture, Benha University, Egypt \\ Corresponding author: alsaeed.algedwy@ fagr.bu.edu.eg
}

\begin{abstract}
Two field experiments were carried out at the Farm of Agric. Res. and Exp. Center of Fac. of Agric. Moshtohor, Benha University, Toukh Directorate, Qalyubia Governorate, Egypt, during two successive summer growing seasons of 2015 and 2016 to study the effect of three water stress, i.e. normal irrigation, skipping the second irrigation (skipping one irrigation during vegetative growth stage) and skipping the fifth irrigation (skipping one irrigation during kernels filling stage) and four nitrogen fertilizer rates, i.e. $0,50,100$ and $150 \mathrm{~kg}$ $\mathrm{N} /$ fed as well as three potassium fertilizer rates, i.e. 0,24 and $48 \mathrm{~kg} \mathrm{~K}_{2} \mathrm{O} /$ fed on growth, yield and its components as well as some kernels chemical properties of maize (white single cross hybrid 2031 for Misr hytech Seed Int.). Results of combined analysis of the two seasons showed that kernels filling stage was the most sensitive to water deficit stress and preventing irrigation at this stage (skipping the $5^{\text {th }}$ irrigation) caused marked decrease in mean values of allmost maize yield and its components, while, full irrigation treatment appeared to be the best irrigation treatment sine it enhanced all maize traits under study. Planting maize under water stress by skipping the $2^{\text {nd }}$ irrigation and skipping the $5^{\text {th }}$ irrigation significantly decreased mean values of grain yield/fed $(\mathrm{kg})$ by 25.49 and $41.04 \%$ respectively, compared to mean values of grain yield/fed $(\mathrm{kg})$ of maize under normal irrigation. Planting maize when received $150 \mathrm{~kg} \mathrm{~N} / \mathrm{fed}$ caused significant increase in all mean values of maize traits under study such as plant height $(\mathrm{cm})$, ear height $(\mathrm{cm})$, No. of ears/fed, ear diameter $(\mathrm{cm})$, ear length $(\mathrm{cm})$, No. of rows/ear, No. of kernels/row, No. of kernels/ear, ear weight (g), kernels weight/ear (g), kernels shelling $(\%), 100$-kernel weight $(\mathrm{g})$, ear yield/fed $(\mathrm{kg})$, grain yield/fed $(\mathrm{kg})$, stover yield/fed $(\mathrm{kg})$, biological yield/fed $(\mathrm{kg})$, harvest index $(\%)$, kernels nitrogen content $(\%)$, kernels crude protein $(\%)$, nitrogen uptake/fed $(\mathrm{kg})$ and protein yield/fed $(\mathrm{kg})$ Meanwhile, the highest mean values of potassium use efficiency (KUE) which were recorded from growing maize when received $100 \mathrm{~kg} \mathrm{~N} / \mathrm{fed}$. Growing maize under the higher potassium rate (48 $\mathrm{kg} \mathrm{K} \mathrm{K}_{2} \mathrm{O} / \mathrm{fed}$ ) was produced the maximum mean values of plant height $(\mathrm{cm})$, No. of ears/fed, ear length $(\mathrm{cm})$, No. of kernels/row, No. of kernels/ear, ear weight (g), kernels weight/ear (g), 100-kernel weight (g), kernels shelling $(\%)$, ear yield/fed $(\mathrm{kg})$, grain yield/fed $(\mathrm{kg})$, stover yield/fed $(\mathrm{kg})$, biological yield/fed $(\mathrm{kg})$, harvest index $(\%)$, kernels potassium content $(\%)$, nitrogen uptake/fed $(\mathrm{kg})$ and protein yield/fed $(\mathrm{kg})$ while, the highest mean values of KUE which were recorded from growing maize when received $24 \mathrm{~kg} \mathrm{~K} / \mathrm{O} / \mathrm{fed}$. The first order interactions between (normal irrigation X $150 \mathrm{Kg} \mathrm{N} / \mathrm{fed}$ ), (normal irrigation $\mathrm{X} 48 \mathrm{~kg} \mathrm{~K} 2 \mathrm{O} / \mathrm{fed}$ ) and $(150 \mathrm{Kg}$ $\mathrm{N} / \mathrm{fed} \mathrm{X} 48 \mathrm{~kg} \mathrm{~K}_{2} \mathrm{O} / \mathrm{fed}$ ) as well as the second order interaction between normal irrigation X $150 \mathrm{Kg} \mathrm{N} / \mathrm{fed} \mathrm{X} 48$ $\mathrm{kg} \mathrm{K}_{2} \mathrm{O} / \mathrm{fed}$ ) were significantly recorded the greatest mean values of maize yield and its components as compared with the others interactions. It could be summarized that grown maize under full irrigation and fertilization by $150 \mathrm{Kg} \mathrm{N}+48 \mathrm{~kg} \mathrm{~K}_{2} \mathrm{O} /$ fed in order to maximizing its productivity.
\end{abstract}

Keywords:Maize, water stress, skipping irrigation, nitrogen fertilizer and potassium fertilizer.

\section{Introduction:}

In Egypt, maize (Zea mays, L.) is considered as one of the main cereal crops, comes the third after wheat and rice. Maize is very essential either for the human food or animal feeding and a common ingredient for industrial products. It plays a vital source of daily human food because their flour mixed with wheat flour by $20 \%$ for bread making. Also, maize is used as a feed for livestock whether fresh, silage or grains. Therefore, a great attention should be paid to raise maize productivity by maximizing yield per unit area in order to reduce the gap between its production and consumption. Where, maize is well known for its high demand for nutrients and other production inputs. Thereby, among factors that enhances maize productivity through growing high yielding hybrids under the optimum plant population density and applying the optimum nitrogen fertilizer rate. World cultivated area of maize in 2018 year reached 461.27 million fed $\left(\mathrm{fed}=4200 \mathrm{~m}^{2}\right)$; the total production was 1147.62 million tons, with an average productivity of $2487.95 \mathrm{~kg}$ grain/fed while, the growing area of maize in Egypt is about 2.228 million fed with a total grain yield of 7.30 million tons, with an average production/fed was about $3274.62 \mathrm{~kg}$ (www.fao.org). The total production supplies $40-50 \%$ of the require consumption with a reduction gap of 50-60\% which has to be filled via importation.

Water is the most abundant constituent of living things. The living tissues of plants usually contain more than $70 \%$ by weight of water and maintenance of satisfactory water content is essential for the plant tissues water content can markedly influence processes of growth and metabolism. All land plants 
are to some degree adapted to the unfavorable water regime of their habitat, but some species can tolerate far more unfavorable drought stresses than can other species (Cattivelliet al. 2008). Generally there are three basic types of adaptation which can occur, the control of water loss from the plant may be more efficient, the uptake of water may be more efficient and the plant may have a greater ability to grow and metabolize or survive when its tissues are suffering a water deficit (Hall 1978). On the other hand, Hall 1982 and Esfandiariet al. 2008 claimed that water stress influences enzyme activity and this way can influence all metabolic processes. Moreover, lowering potential often synthetic processes are reduced more than breakdown processes. He mentioned also, the level of auxin and cytokinins in the tissue are decreased while the level of abscisic acid and ethylene are increased the auxin change is due to at least partly to raised IAA oxidase activity. Parallely, the period of drought often causes yellowing and later browning of leaves, symptoms similar to senescence. On the other hand, the tolerance to draught under field conditions was studied barely cultivars. It was found that higher proline accumulation during draught were the more tolerant to draught. Derby et al. 2005; Muhammad 2005 and Barnabas et al. 2008 claimed that the unfavorable growth conditions such as water stress, salinity or even heat stress can be tolerated by plants in juvenility rather than those at maturity. this is because plants in juvenile have high concentration of growth promoters such as GA, IAA and CKs It helps significantly in compensating and reduce happen in photosynthesis pathway, mineral absorption and production of inhibitors such as ethylene and ABA when stressed occurred. On the other hand, Al-Kaisi and Yin 2003 found that plants at maturity generally have high concentrations of the inhibitors comparing with the promoters this encourages assimilates transportation from sources to sinks accompanied with fruity parts. the previous discussion clarify results obtained in this study, taking into consideration the hazard effects of water stress on maize plants growth, chemical composition and hence yield and its components especially at the end of the juvenility compare with the early juvenile growth period. Many researchers have reported maize growth, yield, its components and kernels chemical properties decreases when maize grown under water stress at any period of growth periods, i.e. vegetative, flowering and seed filling periods (Cakir 2004; Cakmak 2005; Derby et al. 2005; RimskiKorsakov et al. 2009; Shiraziet al. 2011; Waraichet al. 2011; Aslamet al. 2013; Haghjooet al. 2013; Gheysariet al. 2015; Hammadet al. 2015; Paschalidiset al. 2015; Amanullahet al. 2016; Azab 2016; Miet al. 2018;Ul-Allah et al. 2020 and Wang et al. 2020).

Nitrogen is the component of protoplasm, chlorophyll, proteins, nucleic acids and plays a vital role in both vegetative and reproductive phase of crop growth. Maize has been recognized as a heavy feeder and uses more of nitrogen than any other nutrient element. Many reports indicated that nitrogen fertilizer has more influence on the allmost growth and yield maize traits than any other plant nutrient because it is the nutrient most often deficient in the Egyptian soils. Thus, increasing application of nitrogen fertilizer rates led to significant increases in allmost growth, yield and its attributes and kernels quality traits of maize plants (Derby et al. 2005; Law-Ogbomo and Law-Ogbomo 2009; RimskiKorsakov et al. 2009; El-Gedwyet al. 2011; Shiraziet al. 2011; Waraichet al. 2011; Zingore 2011; Haghjooet al. 2013; Gheysariet al. 2015; Hammadet al. 2015; Paschalidiset al. 2015; Azab 2016; Gharibiet al. 2016; Sapkotaet al. 2017; Hirniak 2018; El-Habbaket al. 2019; El-Hosaryet al. 2019 a \& b and Wang et al. 2020)

Potassium is one of the principle plant nutrients underpinning crop yield production and quality determination, although it is not an integral component of any cellular organelle or structural part of the plant. While involved in many physiological processes, potassium's impact on water relations, photosynthesis, assimilate transport, protein synthesis and enzyme activation can have direct consequences on crop productivity. Potassium deficiency can lead to a reduction in both the No. of leaves produced and the size of individual leaves. Coupling this reduced amount of photosynthetic source material with a reduction in the photosynthetic rate/unit leaf area, and the result is an overall reduction in the amount of photosynthetic assimilates available for growth (Jordan-Meille L. and S. Pellerin, 2004). The production of less photosynthetic assimilates and reduced assimilate transport out of the leaves to the developing kernels greatly contributes to the negative consequences that deficiencies of potassium have on yield and quality production. Goals aimed toward increasing crop productivity and improved qualities dictate either increased potassium supply or more efficient use of potassium. Many researchers have reported maize growth, yield, its components and kernels chemical properties increases in response to increasing potassium fertilization (Cakmak 2005; Bruns and Ebelhar 2006; Wiebold and Scharf 2006; Pettigrew 2008; Law-Ogbomo and LawOgbomo 2009; Niuet al. 2011; Tabatabaii, et al. 2011; Waraichet al. 2011; Zingore 2011; Ahmad et al. 2012; Aslamet al. 2013; El-Dissokyet al. 2013; Paschalidiset al. 2015; Amanullahet al. 2016; Hirniak 2018; Jianget al. 2018;Jasaret al. 2019 and Ul-Allah et al. 2020).

The aim of this investigation was designed to study the effect of water stress treatments with soil fertilized by nitrogen and potassium fertilizer rates on growth, yield components, yield and kernels chemical properties of maize. 


\section{Materials and Methods:}

Two field experiments were carried out at the Farm of Agric. Res. and Exp. Center of Fac. of Agric. Moshtohor, Benha University, Toukh Directorate, Qalyubia Governorate, Egypt, during two successive summer growing seasons of 2015 and 2016 to study the effect of water stress with soil fertilized by nitrogen and potassium rates on the growth traits, yield components, yield and kernels chemical properties of maize single cross hybrid 2031 for Misr Hytech Seed Int. (S.C. 2031).

\section{Soil analysis:}

Soil texture of the experimental site was clay textured of pH nearly of 8.0. Soil samples were taken before sowing of crop to depth of $0-30 \mathrm{~cm}$ for chemical and mechanical properties analyses of the experimental soil were determined according to the standard procedures described by Rowell (1995) and represented in Table 1.

Table 1: Chemical and mechanical properties of the experimental soil units at planting maize (Average the 2015 and 2016 seasons.

\begin{tabular}{|c|c|c|c|c|c|c|c|c|c|}
\hline \multicolumn{10}{|c|}{ Chemical analysis } \\
\hline \multirow{2}{*}{$\begin{array}{c}\text { E.C. } \\
\text { (ds/m) }\end{array}$} & \multirow{2}{*}{$\begin{array}{c}\text { pH } \\
(1: 2.5)\end{array}$} & \multirow{2}{*}{$\begin{array}{c}\mathrm{CaCo}_{3} \\
(\%)\end{array}$} & \multirow{2}{*}{$\begin{array}{c}\text { O.M } \\
(\%)\end{array}$} & \multicolumn{3}{|c|}{ Total $(\%)$} & \multicolumn{3}{|c|}{ Available (mg/kg ) } \\
\hline & & & & $\mathbf{N}$ & $\mathbf{P}$ & $\mathbf{K}$ & $\mathbf{N}$ & $\mathbf{P}$ & $\mathbf{K}$ \\
\hline 2.36 & 8.08 & 3.19 & 2.29 & 0.165 & 0.122 & 0.156 & 59.52 & 24.51 & 230.21 \\
\hline \multicolumn{10}{|c|}{ Soluble cations and anions ( $\mathrm{ppm}$ ) } \\
\hline $\mathbf{C a}^{++}$ & $\mathbf{M g}^{++}$ & $\mathbf{K}^{+}$ & $\mathbf{N a}^{+}$ & & & $\mathrm{Co}^{--}$ & $\mathbf{H ~ C}$ & & So4-- \\
\hline 185.47 & 47.39 & 50.46 & 201.57 & & & 0.00 & 336. & & 531.65 \\
\hline \multicolumn{10}{|c|}{ Mechanical analysis (Particle size distribution) } \\
\hline \multicolumn{2}{|c|}{ Course sand $(\%)$} & Find sand $(\%)$ & \multicolumn{2}{|c|}{ Silt (\%) } & \multicolumn{2}{|c|}{ Clay $(\%)$} & \multicolumn{3}{|c|}{ Texture grade } \\
\hline \multicolumn{2}{|c|}{5.07} & 24.95 & \multicolumn{2}{|c|}{13.05} & \multicolumn{2}{|c|}{56.93} & \multicolumn{3}{|c|}{ Clay } \\
\hline
\end{tabular}

Each experiment included thirty six treatments, which were the combination of three water stress treatments, four nitrogen fertilizer rates and three potassium fertilizer rates.

\section{The levels of these factors were as follows:}

\section{A- Water stress treatments:}

1) Normal irrigation (NI), maize grown under full irrigation, Irrigation at 10 (El-mohayah), $25,40,55,70,84$ and 100 days after sowing.

2) Skipping the second irrigation $(\mathrm{SCI})$, maize grown under irrigation at 10, 40, 55, 70, 84 and 100 days after sowing (water stress at vegetative stage).

3) Skipping the fifth irrigation (SFI), maize grown under irrigation at 10, 25, 40, 55, 85 and 100 days after sowing (water stress at kernels filling stage).

\section{B- Nitrogen fertilizer rates:}

1) Without nitrogen added (control).

2) $50 \mathrm{~kg} \mathrm{~N} / \mathrm{fed}$.

3) $100 \mathrm{~kg} \mathrm{~N} / \mathrm{fed}$.

4) $150 \mathrm{~kg} \mathrm{~N} / \mathrm{fed}$.
Nitrogen fertilizer was applied in form of urea (46 $\% \mathrm{~N})$ and divided into two equal parts and applied side dressed before the first and third irrigations in each season.

\section{C- Potassium fertilizer rates:}

1) Without potassium added (control).

2) $24 \mathrm{~kg} \mathrm{~K}_{2} \mathrm{O} /$ fed.

3) $48 \mathrm{~kg} \mathrm{~K}_{2} \mathrm{O} /$ fed.

Potassium fertilizer was applied in form of potassium sulphate $\left(48 \% \mathrm{~K}_{2} \mathrm{O}\right)$ in one dose before the first irrigation in each season.

The preceding winter crop in two seasons was wheat (Triticumaestivum, L.). The experimental design was laid out using split-split plot design in four replications. Each of the three water stress were distributed in the main plots, whereas the four nitrogen fertilizer rates were arranged at random in sub-plots and the three rates of potassium fertilizer were assigned at random in sub-sub plots. The subsub plot area was $19.88 \mathrm{~m}^{2}$ and contained seven ridges of $4 \mathrm{~m}$ long and $71 \mathrm{~cm}$ apart. Phosphorous fertilizer was applied in form of calcium super phosphate $\left(\begin{array}{lll}12.5 & \% & \mathrm{P}_{2} \mathrm{O}_{5}\end{array}\right)$ at a rate of $100 \mathrm{~kg} / \mathrm{fed}$ 
during soil preparation in each season. Maize planting was done by the local method of dibbling 2 kernels in each hill by hand with distance between hills was $25 \mathrm{~cm}$ apart on May $21^{\text {th }}$ and $26^{\text {th }}$ of in the first season (2015) and the second season (2016), respectively. Maize plants were thinned at 24 days after sowing to one plant/hill. Maize plants were harvested on $20^{\text {th }}$ and $25^{\text {th }}$ of September in the first and the second seasons, respectively. The other agricultural practices were kept the same as normally practiced in maize fields according to the recommendations of Ministry of Agriculture and Land Reclamation, except for the factors under study.

\section{Studied traits:}

At harvest, Ten plants were chosen from the five center ridges at random from each sub-sup plots to determine plant height $(\mathrm{cm})$ and ear height $(\mathrm{cm})$. Whereas, No. of ears/fed were estimated from the whole plants in the five center ridges. As well as, ten ears were chosen from the five center ridges at random from each sub-sub plots to determine ear diameter $(\mathrm{cm})$, ear length $(\mathrm{cm})$, No. of rows/ear, No. of kernels/row, No. of kernels/ear, ear weight $(\mathrm{g})$, kernels weight/ear (g), 100-kernel weight (g) and kernels shelling (\%). Whereas, ear yield/fed $(\mathrm{kg})$, stover yield/fed $(\mathrm{kg})$, grain yield/fed $(\mathrm{kg})$, biological yield/fed $(\mathrm{kg})$ and harvest index (\%) were estimated from the whole plants in the five center ridges, as well as calculated nitrogen use efficiency (NUE) and potassium use efficiency (KUE).NUE ( $\mathrm{kg}$ grains $/ \mathrm{kg}$ $\mathrm{N})$ andKUE (kg grains/kgK) were calculated according to Barbar (1976), as follows:

$$
\begin{aligned}
& \text { NUE }=\frac{\text { Grain yield of treatment }(\mathrm{kg} / \mathrm{fed})-\text { Grain yield of control }(\mathrm{kg} / \mathrm{fed})}{\text { Nitrogen applied }(\mathrm{kg} / \mathrm{fed})} \\
& \mathrm{KUE}=\frac{\text { Grain yield of treatment }(\mathrm{kg} / \mathrm{fed})-\text { Grain yield of control }(\mathrm{kg} / \mathrm{fed})}{\text { Potassium applied }(\mathrm{kg} / \mathrm{fed})}
\end{aligned}
$$

Maize kernels samples were taken after harvest at random from all kernels of ten ears to determine:

1- Kernels nitrogen content (\%) was determinate according to the modified micro Kjeldahlmethod (A. O. A. C., 1990).

2- Kernels potassium content (\%) was assayed using a flame spectrophotometer (Corning 400, UK) using the standard method outlined by Jackson (1973).

3- Kernels crude protein content (\%) was calculated by multiplying kernels nitrogen content (\%) X 6.25 (A. O. A. C., 1990).

4- Nitrogen uptake $(\mathrm{kg} / \mathrm{fed})=$ Grain yield/fed $(\mathrm{kg}) \mathrm{x}$ kernels nitrogen content (\%).

5- Protein yield $(\mathrm{kg} / \mathrm{fed})=$ Grain yield $/$ fed $(\mathrm{kg}) \mathrm{x}$ Kernels crude protein content (\%).

\section{Statistical analysis:}

Analysis of variance was performed using MSTATC statistical software package (Freed, 1991). Before conducting a combined analysis over years, error variances were tested for homogeneity by using Bartlett test and mean combined comparisons were performed using the least significant differences (L.S.D) test with a significance level of $5 \%$ by Gomez and Gomez (1984).

\section{Results and Discussion:}

\section{1) Effect of water stress:}

Results in Table 2 indicated that there were significant differences among irrigation treatments, i.e. (normal irrigation, skipping the second irrigation and skipping the fifth irrigation), but the differences in mean values of ear diameter $(\mathrm{cm})$, kernels shelling $(\%)$ and kernels potassium content (\%) between water stress by skipping the second irrigation and normal irrigation, also the differences in mean values of plant height $(\mathrm{cm})$, ear height $(\mathrm{cm})$ and stover yield/fed (kg) between water stress by skipping the fifth irrigation and normal irrigation treatment, as well as the differences in mean values of ear length (cm), No. of rows/ear, biological yield/fed $(\mathrm{kg})$, kernels nitrogen content $(\%)$ and kernels potassium content $(\%)$ between water stress by skipping the fifth and the second irrigation not reach the level of significance in the combined analysis of 2015 and 2016 seasons. Data reveal that normal irrigation treatment appeared to be the best irrigation treatment sine it enhanced all maize traits, i.e. ear diameter $(4.755 \mathrm{~cm})$, ear length $(20.46 \mathrm{~cm})$, No. of rows/ear (11.72 rows), No. of kernels/row (36.25 kernels), No. of kernels/ear (429.47 kernels), ear weight (187.23 g), kernels weight/ear (146.49 g), kernels shelling (76.50\%), 100-kernel weight (33.33 g), ear yield/fed $(3465.52 \mathrm{~kg})$, grain yield/fed $(2725.96 \mathrm{~kg})$, biological yield/fed $(7510.36 \mathrm{~kg})$, harvest index (34.44\%), NUE (20.79 kg grains/kg N), KUE (18.45 kg grains $/ \mathrm{kg} \mathrm{K}$ ), kernels nitrogen content (1.981 \%), kernels potassium content $(0.546 \%)$, kernels crude protein $(12.38 \%)$, nitrogen uptake/fed $(56.68 \mathrm{~kg})$ and protein yield/fed $(354.24 \mathrm{~kg})$ followed by the other treatments including (skipping the second irrigation then skipping the fifth irrigation). While, in mean values of plant height $(283.99 \mathrm{~cm})$, ear height $(142.55$ $\mathrm{cm})$, No. of ears/fed (24.49 thousand ears) and stover yield/fed (4044.84 kg) planting maize under normal irrigation treatment significantly surpassed the other two irrigation treatments followed by skipping the fifth irrigation and skipping the second irrigation, in a descending order. The decreases ratios between planting maize under water stress by skipping the second irrigation and skipping the fifth irrigation as compared with normal irrigation treatment were 15.67 and $0.94 \%$ for plant height; 21.66 and $2.50 \%$ for ear height; 8.49 and $4.94 \%$ for No. of ears/fed; 2.52 and $12.09 \%$ for ear diameter; 13.54 and $20.82 \%$ 
for ear length; 4.35 and $7.17 \%$ for No. of rows/ear; 14.81 and $21.66 \%$ for No. of kernels/row; 18.33 and $26.97 \%$ for No. of kernels/ear; 21.51 and $37.89 \%$ for ear weight; 22.23 and $40.56 \%$ for kernels weight/ear; 0.97 and $4.63 \%$ for kernels shelling;4.98 and $19.05 \%$ for 100 -kernel weight; 24.93 and 38.50 $\%$ for ear yield/fed; 25.49 and $41.04 \%$ for grain yield/fed; 10.48 and $2.78 \%$ for stover yield/fed; 17.15 and $19.26 \%$ for biological yield/fed; 10.80 and $28.28 \%$ for harvest index; 21.60 and $37.95 \%$ for NUE; 19.30 and $36.80 \%$ for KUE; 6.16 and $8.28 \%$ for kernels nitrogen content; 8.61 and $16.30 \%$ for kernels potassium content; 6.14 and $8.24 \%$ for kernels crude protein; 30.10 and $45.85 \%$ for nitrogen uptake/fed in addition to 30.10 and $45.86 \%$ for protein yield/fed, respectively.It was clear that the decreases in mean values of allmost maize traits under water stress at filling kernels may be due to the this period showed the highest sensitivity to drought stress and gave the lowest values of yield, its components and some chemical properties of maize kernels. These results are in compatible with those found byCakir 2004; Cakmak 2005; Derby et al. 2005; Rimski-Korsakov et al. 2009; Shiraziet al. 2011; Waraichet al. 2011; Aslamet al. 2013; Haghjooet al. 2013; Gheysariet al. 2015; Hammadet al. 2015; Paschalidiset al. 2015; Amanullahet al. 2016; Azab 2016; Miet al. 2018;Ul-Allah et al. 2020 and Wang et al. 2020.

\section{2) Effect of nitrogen fertilizer rates:}

Results illustrated in Table $\mathbf{3}$ indicated that allmost growth, yield and its component traits as well as some chemical properties of maize kernels were significantly increased with increasing nitrogen fertilizer rates from 0 up to $150 \mathrm{~kg} \mathrm{~N} /$ fed under study, but the differences between nitrogen fertilizer rates of 100 and $150 \mathrm{~kg} \mathrm{~N} /$ fed on mean values of ear height (cm) and No. of rows/earas well as, the differences in mean values of KUE ( $\mathrm{kg}$ grains $/ \mathrm{kg} \mathrm{K}$ ) between 0 and $50 \mathrm{~kg} \mathrm{~N} / \mathrm{fed}$ also, among 150 and $0 \mathrm{~kg} \mathrm{~N} / \mathrm{fed} \mathrm{not}$ reach the level of significance. Meanwhile, mean values of NUE ( $\mathrm{kg}$ grains $/ \mathrm{kg} \mathrm{N}$ ) and kernels potassium content (\%) of maize were not significantly affected by rising nitrogen fertilizer rates in the combined analysis of both seasons. Planting maize under soil fertilized by the highest nitrogen rate $(150 \mathrm{~kg} \mathrm{~N} / \mathrm{fed})$ significantly gave the maximum mean values of plant height $(295.90 \mathrm{~cm})$, ear height $(144.60 \mathrm{~cm})$, No. of ears/fed (26.58 thousand ears), ear diameter $(5.114 \mathrm{~cm})$, ear length $(21.65 \mathrm{~cm})$, No. of rows/ear (12.02 rows), No. of kernels/row (40.05 kernels), No. of kernels/ear (482.86 kernels), ear weight (211.99 g), kernels weight/ear (172.91 g), kernels shelling (81.32\%), 100-kernel weight (36.04 g), ear yield/fed (4191.64 $\mathrm{kg}$ ), grain yield/fed (3419.75 kg), stover yield/fed (4978.56 kg), biological yield/fed (9170.19 kg), harvest index (36.94\%), kernels nitrogen content $(2.124 \%)$, kernels crude protein $(13.27 \%)$, nitrogen uptake/fed $(73.26 \mathrm{~kg})$ and protein yield/fed (457.87 $\mathrm{kg}$ ). However, the highest mean value of KUE (19.79 $\mathrm{kg}$ grains $/ \mathrm{kg} \mathrm{K}$ ) which was recorded from growing maize when received $100 \mathrm{~kg} \mathrm{~N} / \mathrm{fed}$. The superiority ratios between sowing maize when received $150 \mathrm{~kg}$ $\mathrm{N} /$ fed and each of 100,50 and $0 \mathrm{~kg} \mathrm{~N} /$ fed were 4.70 , 12.53 and $27.76 \%$ for plant height; $4.84,12.48$ and $27.73 \%$ for ear height; $6.02,18.71$ and $36.10 \%$ for No. of ears/fed; 9.21, 17.98 and $32.54 \%$ for ear diameter; 9.79, 24.21 and $58.38 \%$ for ear length; 3.62, 9.07 and $15.13 \%$ for No. of rows/ear; 12.50, 35.62 and $80.41 \%$ for No. of kernels/row; 16.44, 47.57 and $106.61 \%$ for No. of kernels/ear; 21.23, 61.92 and $155.84 \%$ for ear weight; $25.51,80.49$ and $204.15 \%$ for kernels weight/ear; 3.72, 12.00 and $19.64 \%$ for kernels shelling; 8.29, 23.13 and 49.85 $\%$ for 100-kernel weight; 27.14, 90.02 and $238.95 \%$ for ear yield/fed; 31.57, 111.48 and $302.47 \%$ for grain yield/fed; 9.86, 38.03 and $112.13 \%$ for stover yield/fed; $17.14,57.76$ and $155.89 \%$ for biological yield/fed; 13.00, 35.41 and $61.38 \%$ for harvest index; $6.63,17.48$ and $31.19 \%$ for kernels nitrogen content; 6.59, 17.43 and $31.13 \%$ for kernels crude protein; 39.73, 147.17 and $424.03 \%$ for nitrogen uptake/fedin addition to $39.72,147.18$ and $423.94 \%$ for protein yield/fed, respectively. The increase in growth traits associated with increasing nitrogen fertilization rates may be attributed to the role of nitrogen in enhancement meristematic activity and cell division, which caused increase in internodes length, No. of internodes and both of them. The increase in maize yield and its attributes because of increasing nitrogen fertilizer rates up to $150 \mathrm{~kg} \mathrm{~N} / \mathrm{fed}$ can be easily ascribed to the role of nitrogen in activating growth of plants, consequently enhancement yield components (ear dimension, No. of kernels/row, No. of kernels/ear, ear weight, weight of kernels/ear, as well as 100-kernel weight) and consequently increasing grain yield/unit area. In addition, the increases in kernels nitrogen content $\%$ or kernels crude protein content \% by raising nitrogen rates may be due to the fact that nitrogen for essential for building up to the protoplasm amino acids and proteins. These results are in compatible with those found by Derby et al. 2005; LawOgbomo and Law-Ogbomo 2009; RimskiKorsakov et al. 2009; El-Gedwyet al. 2011; Shiraziet al. 2011; Waraichet al. 2011; Zingore 2011; Haghjooet al. 2013; Gheysariet al. 2015; Hammadet al. 2015; Paschalidiset al. 2015; Azab 2016; Gharibiet al. 2016; Sapkotaet al. 2017; Hirniak 2018; El-Habbaket al. 2019; El-Hosaryet al. 2019 a \& b and Wang et al. 2020. 
Table 2: Mean values of agronomic traits of maize as affected by water stress in the combined analysis of 2015 and 2016 seasons.

\begin{tabular}{|c|c|c|c|c|}
\hline \multirow{2}{*}{ Trait } & \multicolumn{3}{|c|}{ Water stress } & \multirow{2}{*}{$\begin{array}{l}\text { L.S.D. } \\
\text { at } 5 \%\end{array}$} \\
\hline & $\begin{array}{c}\text { Normal } \\
\text { irrigation }\end{array}$ & $\begin{array}{c}\text { Skipping } \\
\text { the } 2^{\text {nd }} \text { irrigation }\end{array}$ & $\begin{array}{c}\text { Skipping } \\
\text { the } 5^{\text {th }} \text { irrigation }\end{array}$ & \\
\hline Plant height (cm) & 283.99 & 239.50 & 281.33 & 4.88 \\
\hline Ear height (cm) & 142.55 & 111.67 & 138.99 & 3.73 \\
\hline No. of ears/fed (1000 ears) & 24.49 & 22.41 & 23.28 & 0.41 \\
\hline Ear diameter (cm) & 4.755 & 4.635 & 4.180 & 0.197 \\
\hline Ear length (cm) & 20.46 & 17.69 & 16.20 & 1.86 \\
\hline No. of rows/ear & 11.72 & 11.21 & 10.88 & 0.34 \\
\hline No. of kernels/row & 36.25 & 30.88 & 28.40 & 1.55 \\
\hline No. of kernels/ear & 429.47 & 350.76 & 313.63 & 5.63 \\
\hline Ear weight (g) & 187.23 & 146.96 & 116.29 & 6.11 \\
\hline Kernels weight/ear (g) & 146.49 & 113.92 & 87.08 & 5.22 \\
\hline Kernels shelling (\%) & 76.50 & 75.76 & 72.96 & 0.83 \\
\hline 100-kernel weight (g) & 33.33 & 31.67 & 26.98 & 0.89 \\
\hline Ear yield/fed (kg) & 3465.52 & 2601.48 & 2131.24 & 185.12 \\
\hline Grain yield/fed (kg) & 2725.96 & 2031.09 & 1607.18 & 173.11 \\
\hline Stover yield/fed (kg) & 4044.84 & 3620.80 & 3932.36 & 146.72 \\
\hline Biological yield/fed (kg) & 7510.36 & 6222.28 & 6063.60 & 277.72 \\
\hline Harvest index (\%) & 34.44 & 30.72 & 24.70 & 1.53 \\
\hline NUE (kg grains/kg N) & 20.79 & 16.30 & 12.90 & 0.98 \\
\hline KUE (kg grains/kg K) & 18.45 & 14.89 & 11.66 & 1.29 \\
\hline Kernels nitrogen content (\%) & 1.981 & 1.859 & 1.817 & 0.088 \\
\hline Kernels potassium content $(\%)$ & 0.546 & 0.499 & 0.457 & 0.047 \\
\hline Kernels crude protein (\%) & 12.38 & 11.62 & 11.36 & 0.22 \\
\hline Nitrogen uptake/fed (kg) & 56.68 & 39.62 & 30.69 & 2.75 \\
\hline Protein yield/fed (kg) & 354.24 & 247.63 & 191.79 & 6.88 \\
\hline
\end{tabular}


Table 3: Mean values of agronomic traits of maize as affected by nitrogen fertilizer rates in the combined analysis of 2015 and 2016 seasons.

\begin{tabular}{|c|c|c|c|c|c|}
\hline \multirow{2}{*}{ Trait } & \multicolumn{4}{|c|}{ Nitrogen fertilizer rate (kg N/fed) } & \multirow{2}{*}{$\begin{array}{l}\text { L.S.D. } \\
\text { at } 5 \%\end{array}$} \\
\hline & $\mathbf{0}$ & 50 & 100 & 150 & \\
\hline Plant height (cm) & 231.61 & 262.96 & 282.63 & 295.90 & 10.15 \\
\hline Ear height (cm) & 113.21 & 128.56 & 137.92 & 144.60 & 7.09 \\
\hline No. of ears/fed (1000 ears) & 19.53 & 22.39 & 25.07 & 26.58 & 0.52 \\
\hline Ear diameter $(\mathbf{c m})$ & 3.881 & 4.360 & 4.710 & 5.144 & 0.175 \\
\hline Ear length $(\mathrm{cm})$ & 13.67 & 17.43 & 19.72 & 21.65 & 1.63 \\
\hline No. of rows/ear & 10.44 & 11.02 & 11.60 & 12.02 & 0.41 \\
\hline No. of kernels/row & 22.20 & 29.53 & 35.60 & 40.05 & 2.93 \\
\hline No. of kernels/ear & 233.71 & 327.20 & 414.69 & 482.86 & 10.15 \\
\hline Ear weight (g) & 82.86 & 130.92 & 174.87 & 211.99 & 14.33 \\
\hline Kernels weight/ear (g) & 56.85 & 95.80 & 137.77 & 172.91 & 11.69 \\
\hline Kernels shelling (\%) & 67.97 & 72.61 & 78.40 & 81.32 & 2.25 \\
\hline 100-kernel weight (g) & 24.05 & 29.27 & 33.28 & 36.04 & 2.69 \\
\hline Ear yield/fed (kg) & 1236.67 & 2205.89 & 3296.79 & 4191.64 & 365.62 \\
\hline Grain yield/fed (kg) & 849.69 & 1617.08 & 2599.11 & 3419.75 & 278.37 \\
\hline Stover yield/fed (kg) & 2346.96 & 3606.86 & 4531.64 & 4978.56 & 310.55 \\
\hline Biological yield/fed (kg) & 3583.63 & 5812.75 & 7828.43 & 9170.19 & 489.17 \\
\hline Harvest index (\%) & 22.89 & 27.28 & 32.69 & 36.94 & 2.61 \\
\hline NUE (kg grains/kg N) & -- & 15.35 & 17.50 & 17.14 & N.S. \\
\hline KUE (kg grains/kg K) & 13.23 & 14.41 & 19.79 & 12.57 & 1.61 \\
\hline Kernels nitrogen content $(\%)$ & 1.619 & 1.808 & 1.992 & 2.124 & 0.126 \\
\hline Kernels potassium content $(\%)$ & 0.468 & 0.491 & 0.512 & 0.531 & N.S. \\
\hline Kernels crude protein (\%) & 10.12 & 11.30 & 12.45 & 13.27 & 0.32 \\
\hline Nitrogen uptake/fed (kg) & 13.98 & 29.64 & 52.43 & 73.26 & 4.87 \\
\hline Protein yield/fed (kg) & 87.39 & 185.24 & 327.71 & 457.87 & 12.18 \\
\hline
\end{tabular}




\section{3) Effect of potassium fertilizer rates:}

Results in Table 4 showed that growth, yield, its attributes and kernels chemical properties of maize, i.e. plant height $(\mathrm{cm})$, ear length $(\mathrm{cm})$, No. of ears/fed, No. of kernels/row, No. of kernels/ear, ear weight $(\mathrm{g})$, kernels weight/ear $(\mathrm{g})$, kernels shelling $(\%), 100$-kernel weight $(\mathrm{g})$, ear yield/fed $(\mathrm{kg})$, grain yield/fed $(\mathrm{kg})$, stover yield/fed $(\mathrm{kg})$, biological yield/fed (kg), harvest index (\%), KUE (kg grains/kg $\mathrm{K})$, kernels potassium content (\%), nitrogen uptake/fed $(\mathrm{kg})$ and protein yield/fed $(\mathrm{kg})$ were significantly affected by potassium fertilizer rates, i.e. 0,24 and $48 \mathrm{~kg} \mathrm{~K}_{2} \mathrm{O} / \mathrm{fed}$, but, the differences between potassium fertilizer rates of 24 and $48 \mathrm{~kg} \mathrm{~K}_{2} \mathrm{O} / \mathrm{fed}$ on mean values of kernels potassium content (\%) not reach the level of significance. While, mean values of ear height $(\mathrm{cm})$, ear diameter $(\mathrm{cm})$, No. of rows/ear, NUE ( $\mathrm{kg}$ grains $/ \mathrm{kg} \mathrm{N}$ ), kernels nitrogen content and kernels crude protein were not significant in the combined analysis of both seasons. In general, the higher potassium rate (48 $\mathrm{kg} \mathrm{K} \mathrm{K}_{2} \mathrm{O} / \mathrm{fed}$ ) was more effective in increasing mean values of allmost studied traits, also, produced the maximum mean values of plant height $(273.78 \mathrm{~cm})$, No. of ears/fed $(24.28$ thousand ears), ear length $(19.10 \mathrm{~cm})$, No. of kernels/row (34.46 kernels), No. of kernels/ear (399.02 kernels), ear weight (167.62 g), kernels weight/ear (131.60 g), kernels shelling (76.95 \%), 100-kernel weight (32.29 g), ear yield/fed (3111.83 $\mathrm{kg})$, grain yield/fed $(2455.01 \mathrm{~kg})$, stover yield/fed $(4078.38 \mathrm{~kg})$, biological yield/fed $(7190.21 \mathrm{~kg})$, harvest index $(32.56 \%)$, kernels potassium content $(0.530 \%)$, nitrogen uptake/fed $(49.60 \mathrm{~kg})$ and protein yield/fed $(310.00 \mathrm{~kg})$, meanwhile, the highest mean value of KUE (15.65 kg grains $/ \mathrm{kg} \mathrm{K}$ ) which were recorded from growing maize when received $24 \mathrm{~kg}$ $\mathrm{K}_{2} \mathrm{O} /$ fed.The increases ratios with planting maize when received $48 \mathrm{~kg} \mathrm{~K}_{2} \mathrm{O} /$ fed over each of 24 and 0 $\mathrm{kg} \mathrm{K}_{2} \mathrm{O} /$ fed were 1.77 and $4.49 \%$ for plant height; 4.12 and $7.53 \%$ for No. of ears/fed; 5.06 and 11.89 $\%$ for ear length; 6.65 and $19.78 \%$ for No. of kernels/row; 7.73 and $22.98 \%$ for No. of kernels/ear; 9.94 and $28.56 \%$ for ear weight; 11.82 and $34.01 \%$ for kernels weight/ear; 2.12 and $5.53 \%$ for kernels shelling; 4.67 and $11.96 \%$ for 100-kernel weight; 12.84 and $33.64 \%$ for ear yield/fed; 14.59 and 38.95 $\%$ for grain yield/fed; 5.16 and $12.00 \%$ for stover yield/fed; 8.35 and $20.44 \%$ for biological yield/fed; 7.35 and $20.73 \%$ for harvest index; 4.33 and 14.22 $\%$ for kernels potassium content; 15.91 and $43.35 \%$ for nitrogen uptake/fed in addition to 15.92 and 43.37 $\%$ for protein yield/fed, respectively. The increase in maize traits associated with increasing potassium fertilization rates may be attributed to the role of potassium in many physiological processes, i.e. water relations, photosynthesis, assimilate transport, protein synthesis and enzyme activation can have direct consequences on maize productivity. These results are in compatible with those found byCakmak 2005; Bruns and Ebelhar 2006; Wiebold and Scharf 2006; Pettigrew 2008; Law-Ogbomo and LawOgbomo 2009; Niuet al. 2011; Tabatabaii, et al.
2011; Waraichet al. 2011; Zingore 2011; Ahmad et al. 2012; Aslamet al. 2013; El-Dissokyet al. 2013; Paschalidiset al. 2015; Amanullahet al. 2016; Hirniak 2018; Jianget al. 2018;Jasaret al. 2019 and Ul-Allah et al. 2020.

\section{4) Effect of interaction between water stress and nitrogen fertilizer rates:}

Results in Table 5 showed that interaction effect among water stress treatments (normal irrigation, skipping the second irrigation and skipping the fifth irrigation) and nitrogen fertilizer rates $(0,50,100$ and $150 \mathrm{~kg} \mathrm{~N} / \mathrm{fed}$ ) induced significant different on allmost maize traits under study except, for mean values of ear height $(\mathrm{cm})$, ear diameter $(\mathrm{cm})$, No. of rows/ear, kernels shelling (\%) and kernels potassium content $(\%)$ in the combined analysis of both seasons. Growing maize under full irrigation when received $150 \mathrm{~kg} \mathrm{~N} /$ fed markedly produced the maximum mean values of plant height $(311.88 \mathrm{~cm})$, No. of ears/fed (27.37 thousand ears), ear length $(24.55 \mathrm{~cm})$, No. of kernels/row (45.01 kernels), No. of kernels/ear (561.93 kernels), ear weight (262.71 g), kernels weight/ear (216.98 g), 100-kernel weight (39.23 g), ear yield/fed $(5180.71 \mathrm{~kg})$, grain yield/fed (4280.22 $\mathrm{kg})$, stover yield/fed $(5208.46 \mathrm{~kg})$, biological yield/fed $(10389.17 \mathrm{~kg})$, harvest index $(41.15 \%)$, kernels nitrogen content $(2.243 \%)$, kernels crude protein $(14.02 \%)$, nitrogen uptake/fed $(96.07 \mathrm{~kg})$ and protein yield/fed $(600.44 \mathrm{~kg})$. Meanwhile, the highest mean values of NUE $(21.79 \mathrm{~kg}$ grains $/ \mathrm{kg} \mathrm{N})$ and KUE (23.77 kg grains/kg K) which were recorded from growing maize with normal irrigation treatment when received $100 \mathrm{~kg} \mathrm{~N} / \mathrm{fed}$. Planting maize under water stress by skipping the $5^{\text {th }}$ irrigation without nitrogen added significantly gave the lowest mean values of ear length $(12.34 \mathrm{~cm})$, No. of kernels/row (19.05 kernels), No. of kernels/ear (192.06 kernels), ear weight (61.68 g), kernels weight/ear (40.84 g), 100-kernel weight $(21.25 \mathrm{~g})$, ear yield/fed $(919.50$ $\mathrm{kg})$, grain yield/fed $(609.50 \mathrm{~kg})$, harvest index $(17.80$ $\%)$, KUE (9.25 kg grains $/ \mathrm{kg} \mathrm{K}$ ), kernels nitrogen content $(1.581 \%)$, kernels crude protein $(9.88 \%)$, nitrogen uptake/fed $(9.74 \mathrm{~kg})$ and protein yield/fed $(60.85 \mathrm{~kg})$. While, the lowest mean values of plant height $(208.83 \mathrm{~cm})$, No. of ears/fed (18.37 thousand ears), stover yield/fed $(2079.17 \mathrm{~kg})$ and biological yield/fed $(3215.46 \mathrm{~kg})$ were recorded from sowing maize under water stress by skipping the $2^{\text {nd }}$ irrigation without nitrogen added. Meanwhile, planting maize under water stress by skipping the $5^{\text {th }}$ irrigation when received $50 \mathrm{~kg} \mathrm{~N} /$ fed gave the lowest mean value of NUE by $11.39 \mathrm{~kg}$ grains $/ \mathrm{kg} \mathrm{N}$. Results reported here are in harmony with those obtained by Derby et al. 2005; Rimski-Korsakov et al. 2009; Shiraziet al. 2011; Waraichet al. 2011; Haghjooet al. 2013; Gheysariet al. 2015; Hammadet al. 2015; Paschalidiset al. 2015; Azab 2016; and Wang et al. 2020, found that mean values of maize yield and its components were significantly affected by interaction between water stress and nitrogen fertilizer rates. 
Table 4: Mean values of agronomic traits of maize as affected by potassium fertilizer rates in the combined analysis of 2015 and 2016 seasons.

\begin{tabular}{|c|c|c|c|c|}
\hline \multirow{2}{*}{ Trait } & \multicolumn{3}{|c|}{ Potassium fertilizer rate $\left(\mathrm{kg} \mathrm{K}_{2} \mathrm{O} / \mathrm{fed}\right)$} & \multirow{2}{*}{$\begin{array}{l}\text { L.S.D. } \\
\text { at } 5 \%\end{array}$} \\
\hline & $\mathbf{0}$ & 24 & 48 & \\
\hline Plant height (cm) & 262.02 & 269.02 & 273.78 & 4.22 \\
\hline Ear height (cm) & 127.98 & 131.47 & 133.76 & N.S. \\
\hline No. of ears/fed (1000 ears) & 22.58 & 23.32 & 24.28 & 0.16 \\
\hline Ear diameter (cm) & 4.347 & 4.544 & 4.680 & N.S. \\
\hline Ear length (cm) & 17.07 & 18.18 & 19.10 & 0.78 \\
\hline No. of rows/ear & 11.06 & 11.31 & 11.44 & N.S. \\
\hline No. of kernels/row & 28.77 & 32.31 & 34.46 & 1.75 \\
\hline No. of kernels/ear & 324.45 & 370.38 & 399.02 & 5.11 \\
\hline Ear weight (g) & 130.38 & 152.47 & 167.62 & 6.15 \\
\hline Kernels weight/ear (g) & 98.20 & 117.69 & 131.60 & 5.19 \\
\hline Kernels shelling (\%) & 72.92 & 75.35 & 76.95 & 1.15 \\
\hline 100-kernel weight (g) & 28.84 & 30.85 & 32.29 & 0.79 \\
\hline Ear yield/fed (kg) & 2328.59 & 2757.81 & 3111.83 & 151.33 \\
\hline Grain yield/fed (kg) & 1766.80 & 2142.42 & 2455.01 & 167.42 \\
\hline Stover yield/fed (kg) & 3641.49 & 3878.15 & 4078.38 & 153.55 \\
\hline Biological yield/fed (kg) & 5970.08 & 6635.96 & 7190.21 & 269.85 \\
\hline Harvest index (\%) & 26.97 & 30.33 & 32.56 & 1.57 \\
\hline NUE (kg grains/kg N) & 16.01 & 16.74 & 17.24 & N.S. \\
\hline KUE (kg grains/kg K) & -- & 15.65 & 14.34 & 0.98 \\
\hline Kernels nitrogen content (\%) & 1.832 & 1.893 & 1.932 & N.S. \\
\hline Kernels potassium content $(\%)$ & 0.464 & 0.508 & 0.530 & 0.025 \\
\hline Kernels crude protein $(\%)$ & 11.45 & 11.83 & 12.07 & N.S. \\
\hline Nitrogen uptake/fed (kg) & 34.60 & 42.79 & 49.60 & 2.69 \\
\hline Protein yield/fed (kg) & 216.22 & 267.43 & 310.00 & 6.73 \\
\hline
\end{tabular}


Table 5: Mean values of agronomic traits of maize as affected by interaction between water stress and nitrogen fertilizer rates on in the combined analysis of 2015 and 2016 seasons.

\begin{tabular}{|c|c|c|c|c|c|c|c|c|c|c|c|c|c|}
\hline \multirow{3}{*}{$\begin{array}{l}\text { Trait } \\
\text { Nitrogen }(\mathrm{kg} \mathrm{N} / \mathrm{fed})\end{array}$} & \multicolumn{12}{|c|}{ Water stress } & \multirow{3}{*}{$\begin{array}{l}\text { L.S.D. } \\
\text { at } 5 \%\end{array}$} \\
\hline & \multicolumn{4}{|c|}{ Normal irrigation } & \multicolumn{4}{|c|}{ Skipping the $2^{\text {nd }}$ irrigation } & \multicolumn{4}{|c|}{ Skipping the $5^{\text {th }}$ irrigation } & \\
\hline & $\mathbf{0}$ & 50 & 100 & 150 & $\mathbf{0}$ & 50 & 100 & 150 & $\mathbf{0}$ & $\mathbf{5 0}$ & 100 & 150 & \\
\hline Plant height (cm) & 244.33 & 279.46 & 300.29 & 311.88 & 208.83 & 232.46 & 249.21 & 267.50 & 241.67 & 276.96 & 298.38 & 308.33 & 17.58 \\
\hline Ear height (cm) & 122.75 & 140.33 & 150.67 & 156.46 & 97.46 & 108.42 & 116.08 & 124.71 & 119.42 & 136.92 & 147.00 & 152.63 & N.S. \\
\hline No. of ears/fed (1000 ears) & 20.80 & 23.67 & 26.13 & 27.37 & 18.37 & 21.42 & 24.07 & 25.80 & 19.43 & 22.10 & 25.00 & 26.57 & 0.90 \\
\hline Ear diameter (cm) & 4.117 & 4.575 & 4.933 & 5.396 & 3.917 & 4.446 & 4.838 & 5.342 & 3.608 & 4.058 & 4.358 & 4.696 & N.S. \\
\hline Ear length $(\mathrm{cm})$ & 15.24 & 19.77 & 22.29 & 24.55 & 13.42 & 16.96 & 19.25 & 21.13 & 12.34 & 15.56 & 17.62 & 19.28 & 2.82 \\
\hline No. of rows/ear & 10.91 & 11.44 & 12.03 & 12.48 & 10.38 & 10.97 & 11.56 & 11.95 & 10.04 & 10.65 & 11.22 & 11.62 & N.S. \\
\hline No. of kernels/row & 26.10 & 33.86 & 40.03 & 45.01 & 21.44 & 28.76 & 34.93 & 38.41 & 19.05 & 25.97 & 31.83 & 36.74 & 5.07 \\
\hline No. of kernels/ear & 285.75 & 388.09 & 482.10 & 561.93 & 223.33 & 316.15 & 404.18 & 459.37 & 192.06 & 277.38 & 357.80 & 427.29 & 17.58 \\
\hline Ear weight (g) & 106.81 & 163.34 & 216.04 & 262.71 & 80.09 & 128.96 & 173.30 & 205.49 & 61.68 & 100.45 & 135.26 & 167.76 & 24.82 \\
\hline Kernels weight/ear (g) & 74.33 & 122.10 & 172.54 & 216.98 & 55.37 & 94.58 & 137.26 & 168.48 & 40.84 & 70.73 & 103.50 & 133.26 & 20.25 \\
\hline Kernels shelling (\%) & 69.19 & 74.53 & 79.73 & 82.56 & 68.81 & 73.13 & 79.11 & 82.00 & 65.90 & 70.18 & 76.37 & 79.40 & N.S. \\
\hline 100-kernel weight (g) & 26.08 & 31.80 & 36.20 & 39.23 & 24.82 & 30.23 & 34.38 & 37.24 & 21.25 & 25.78 & 29.26 & 31.65 & 4.66 \\
\hline Ear yield/fed (kg) & 1654.21 & 2858.83 & 4168.33 & 5180.71 & 1136.29 & 2086.71 & 3164.58 & 4018.33 & 919.50 & 1672.13 & 2557.46 & 3375.88 & 633.27 \\
\hline Grain yield/fed (kg) & 1153.06 & 2139.50 & 3331.05 & 4280.22 & 786.51 & 1532.76 & 2508.39 & 3296.70 & 609.50 & 1178.98 & 1957.90 & 2682.34 & 482.15 \\
\hline Stover yield/fed (kg) & 2532.13 & 3734.17 & 4704.63 & 5208.46 & 2079.17 & 3430.71 & 4289.29 & 4684.04 & 2429.58 & 3655.71 & 4601.00 & 5043.17 & $\mathbf{5 3 7 . 8 9}$ \\
\hline Biological yield/fed (kg) & 4186.33 & 6593.00 & 8872.96 & 10389.17 & 3215.46 & 5517.42 & 7453.88 & 8702.38 & 3349.08 & 5327.83 & 7158.46 & 8419.04 & 847.27 \\
\hline Harvest index (\%) & 26.98 & 32.24 & 37.38 & 41.15 & 23.91 & 27.63 & 33.50 & 37.85 & 17.80 & 21.97 & 27.19 & 31.83 & 4.52 \\
\hline NUE (kg grains/kg N) & -- & 19.73 & 21.79 & 20.85 & -- & 14.93 & 17.22 & 16.74 & -- & 11.39 & 13.49 & 13.82 & 2.89 \\
\hline KUE (kg grains/kg K) & 17.78 & 18.32 & 23.77 & 13.94 & 12.67 & 14.09 & 19.82 & 12.96 & 9.25 & 10.80 & 15.77 & 10.82 & 2.79 \\
\hline Kernels nitrogen content (\%) & 1.6675 & 1.9088 & 2.1038 & 2.2425 & 1.6075 & 1.7825 & 1.9688 & 2.0788 & 1.5808 & 1.7329 & 1.9033 & 2.0504 & 0.2182 \\
\hline Kernels potassium content $(\%)$ & 0.5142 & 0.5388 & 0.5588 & 0.5708 & 0.4617 & 0.4871 & 0.5104 & 0.5383 & 0.4271 & 0.4483 & 0.4671 & 0.4846 & N.S. \\
\hline Kernels crude protein (\%) & 10.42 & 11.93 & 13.15 & 14.02 & 10.05 & 11.14 & 12.30 & 12.99 & 9.88 & 10.83 & 11.90 & 12.82 & 0.55 \\
\hline Nitrogen uptake/fed (kg) & 19.38 & 40.94 & 70.32 & 96.07 & 12.83 & 27.46 & 49.58 & 68.62 & 9.74 & 20.51 & 37.40 & 55.09 & 8.44 \\
\hline Protein yield/fed (kg) & 121.11 & 255.90 & 439.51 & 600.44 & 80.20 & 171.61 & 309.85 & 428.84 & 60.85 & 128.21 & 233.77 & 344.34 & 21.10 \\
\hline
\end{tabular}




\section{5) Effect of interaction between water stress and potassium fertilizer rates:}

Mean values of plant height $(\mathrm{cm})$, ear length $(\mathrm{cm})$, No. of kernels/row, No. of kernels/ear, ear weight (g), kernels weight/ear $(\mathrm{g})$, 100-kernel weight $(\mathrm{g})$, ear yield/fed $(\mathrm{kg})$, grain yield/fed $(\mathrm{kg})$, stover yield/fed $(\mathrm{kg})$, biological yield/fed $(\mathrm{kg})$, harvest index (\%), NUE ( $\mathrm{kg}$ grains $/ \mathrm{kg} \mathrm{N}$ ), KUE ( $\mathrm{kg}$ grains $/ \mathrm{kg} \mathrm{K}$ ), nitrogen uptake/fed $(\mathrm{kg})$ and protein yield/fed $(\mathrm{kg})$ of maize were significantly affected by interaction between water stress treatments (full irrigation, skipping the $2^{\text {nd }}$ irrigation and skipping the $5^{\text {th }}$ irrigation) and potassium fertilizer rates (0, 24 and 48 $\left.\mathrm{kg} \mathrm{K}_{2} \mathrm{O} / \mathrm{fed}\right)$. While, mean values of ear height $(\mathrm{cm})$, No. of ears/fed, ear diameter $(\mathrm{cm})$, No. of rows/ear, kernels shelling (\%), kernels nitrogen content (\%), kernels potassium content $(\%)$ and kernels crude protein $(\%)$ were not significant by interaction between water tress and potassium fertilizer rates in the combined analysis of both seasons, as shown in Table 6. Planting maize with full irrigation treatment when received $48 \mathrm{~kg} \mathrm{~K} 2 \mathrm{O} /$ fed significantly produced the maximum mean values of plant height (289.13 $\mathrm{cm})$, ear length $(21.60 \mathrm{~cm})$, No. of kernels/row (39.04 kernels), No. of kernels/ear (467.30 kernels), ear weight (208.12 g), kernels weight/ear (165.92 g), 100-kernel weight (35.12 g), ear yield/fed (3932.72 $\mathrm{kg}$ ), grain yield/fed $(3146.46 \mathrm{~kg})$, stover yield/fed $(4268.03 \mathrm{~kg})$, biological yield/fed $(8200.75 \mathrm{~kg})$, harvest index (37.19\%), NUE (21.17 kg grains $/ \mathrm{kg}$ $\mathrm{N})$, nitrogen uptake/fed $(66.15 \mathrm{~kg})$ and protein yield/fed $(413.42 \mathrm{~kg})$. Meanwhile, the highest mean values of KUE (19.01 kg grains $/ \mathrm{kg} \mathrm{K}$ ) which were recorded from growing maize with full irrigation treatment when received $24 \mathrm{~kg} \mathrm{~K}_{2} \mathrm{O} /$ fed. On the other hand, the lowest mean values of ear length (15.31 $\mathrm{cm})$, No. of kernels/row (25.40 kernels), No. of kernels/ear (276.04 kernels), ear weight (100.05 g), kernels weight/ear $(73.14 \mathrm{~g}), 100$-kernel weight $(25.40 \mathrm{~g})$, ear yield/fed $(1805.31 \mathrm{~kg})$, grain yield/fed $(1330.14 \mathrm{~kg})$, biological yield/fed $(5535.72 \mathrm{~kg})$, harvest index $(21.90 \%)$, NUE (12.11 kg grains $/ \mathrm{kg}$ $\mathrm{N})$, nitrogen uptake/fed $(24.91 \mathrm{~kg})$ and protein yield/fed $(155.71 \mathrm{~kg})$, which were obtained from sowing maize under water stress by skipping the $5^{\text {th }}$ irrigation without potassium added, while, the lowest mean value of KUE (11.32 kg grains $/ \mathrm{kg} \mathrm{K}$ ) which was recorded from growing maize with the same water stress when received $48 \mathrm{~kg} \mathrm{~K}_{2} \mathrm{O} / \mathrm{fed}$. While, sowing maize under water stress by skipping the $2^{\text {nd }}$ irrigation without potassium added recorded the minimum mean values of plant height $(232.06 \mathrm{~cm})$ and stover yield/fed $(3380.59 \mathrm{~kg})$. These results agree with those reported by Cakmak 2005; Waraichet al. 2011; Aslamet al. 2013;Paschalidiset al. 2015; Amanullahet al. 2016 and Ul-Allah et al. 2020, found that mean values of maize yield and its components were significantly affected by interaction between water stress and potassium fertilizer rates.

\section{6) Effect of interaction between nitrogen and potassium fertilizer rates:}

Results in Table 7 showed that interaction effect among nitrogen fertilizer rates $(0,50,100$ and $150 \mathrm{~kg}$ $\mathrm{N} / \mathrm{fed})$ and potassium fertilizer rates $(0,24$ and $48 \mathrm{~kg}$ $\mathrm{K}_{2} \mathrm{O} / \mathrm{fed}$ ) induced significant different on all maize yield and its related traits except, for mean values of ear diameter $(\mathrm{cm})$, No. of rows/ear and kernels potassium content $(\%)$ in the combined analysis of both seasons. The highest mean values of plant height $(299.29 \mathrm{~cm})$, ear height $(146.21 \mathrm{~cm})$, No. of ears/fed (27.03thousand ears), ear length $(22.32 \mathrm{~cm})$, No. of kernels/row (41.58kernels), No. of kernels/ear (505.89kernels), ear weight $(222.90 \mathrm{~g})$, kernels weight/ear (184.53 g), kernels shelling $(82.60 \%)$, 100-kernel weight (36.73 g), ear yield/fed (4446.96 $\mathrm{kg}$ ), grain yield/fed $(3681.83 \mathrm{~kg})$, stover yield/fed $(5155.88 \mathrm{~kg})$, biological yield/fed $(9602.83 \mathrm{~kg})$, harvest index (38.04\%), kernels nitrogen content $(2.157 \%)$, kernels crude protein $(13.48 \%)$, nitrogen uptake/fed $(79.96 \mathrm{~kg})$ and protein yield/fed (499.74 $\mathrm{kg}$ ) were recorded from maize plants which fertilized by $150 \mathrm{~kg} \mathrm{~N}$ and $48 \mathrm{~kg} \mathrm{~K} \mathrm{~K}_{2} \mathrm{O} / \mathrm{fed}$. While, the highest mean values of NUE (18.74 $\mathrm{kg}$ grains $/ \mathrm{kg} \mathrm{N}$ ) and KUE (20.96 kg grains $/ \mathrm{kg} \mathrm{K}$ ) which were obtained from maize under soil fertilized by $100 \mathrm{~kg} \mathrm{~N} / \mathrm{fed}$ when received 48 and $24 \mathrm{~kg} \mathrm{~K} \mathrm{~K}_{2} \mathrm{O} /$ fed respectively. On the other hand, growing maize without nitrogen and potassium fertilizers added markedly recorded the lowest mean values in plant height $(220.83 \mathrm{~cm})$, ear height $(107.92 \mathrm{~cm})$, No. of ears/fed $(18.40$ thousand ears), ear length $(12.14 \mathrm{~cm})$, No. of kernels/row (17.09 kernels), No. of kernels/ear (175.95 kernels), ear weight $(58.07 \mathrm{~g})$, kernels weight/ear (38.23 g), kernels shelling (65.68 \%), 100kernel weight $(21.73 \mathrm{~g})$, ear yield/fed $(812.54 \mathrm{~kg})$, grain yield/fed $(535.05 \mathrm{~kg})$, stover yield/fed $(2083.54$ $\mathrm{kg}$ ), biological yield/fed $(2896.08 \mathrm{~kg})$, harvest index $(18.28 \%)$, kernels nitrogen content (1.551 \%), kernels crude protein $(9.69 \%)$, nitrogen uptake/fed $(8.39 \mathrm{~kg})$ and protein yield/fed $(52.41 \mathrm{~kg})$. While, the lowest mean value of NUE (14.75 kg grains $/ \mathrm{kg} \mathrm{N}$ ) which was recorded when planting maize under soil fertilized by $50 \mathrm{~kg}$ N/fed without potassium fertilizers added. Meanwhile, sowing maize under soil fertilized by $150 \mathrm{~kg} \mathrm{~N}$ and $48 \mathrm{~kg} \mathrm{~K}_{2} \mathrm{O} / \mathrm{fed}$ significantly recorded the lowest mean value of KUE by $11.58 \mathrm{~kg}$ grains $/ \mathrm{kg} \mathrm{K}$. Such results are in accordance with those obtained by Law-Ogbomo and Law-Ogbomo 2009; Waraichet al. 2011; Zingore 2011; Paschalidiset al. 2015 and Hirniak 2018, which reported that there was significantly difference among interaction between nitrogen and potassium fertilizer rates of mean values of maize yield and its components. 
Table 6: Mean values of agronomic traits of maize as affected by interaction between water stress and potassium fertilizer rates on in the combined analysis of 2015 and 2016

\begin{tabular}{|c|c|c|c|c|c|c|c|c|c|c|}
\hline \multirow{3}{*}{$\begin{array}{l}\text { Trait } \\
\qquad \text { Potassium }\left(\mathrm{kg} \mathrm{K}_{2} \mathrm{O} / \mathrm{fed}\right)\end{array}$} & \multicolumn{9}{|c|}{ Water stress } & \multirow{3}{*}{$\begin{array}{l}\text { L.S.D. } \\
\text { at } 5 \%\end{array}$} \\
\hline & \multicolumn{3}{|c|}{ Normal irrigation } & \multicolumn{3}{|c|}{ Skipping the $2^{\text {nd }}$ irrigation } & \multicolumn{3}{|c|}{ Skipping the $5^{\text {th }}$ irrigation } & \\
\hline & $\mathbf{0}$ & 24 & 48 & $\mathbf{0}$ & 24 & 48 & $\mathbf{0}$ & 24 & 48 & \\
\hline Plant height (cm) & 278.41 & 284.44 & 289.13 & 232.06 & 240.31 & 246.13 & 275.59 & 282.31 & 286.09 & 7.31 \\
\hline Ear height (cm) & 139.84 & 142.72 & 145.09 & 108.19 & 112.06 & 114.75 & 135.91 & 139.63 & 141.44 & N.S. \\
\hline No. of ears/fed (1000 ears) & 23.68 & 24.35 & 25.45 & 21.50 & 22.51 & 23.23 & 22.58 & 23.10 & 24.15 & N.S. \\
\hline Ear diameter $(\mathbf{c m})$ & 4.588 & 4.778 & 4.900 & 4.441 & 4.656 & 4.809 & 4.013 & 4.197 & 4.331 & N.S. \\
\hline Ear length (cm) & 19.24 & 20.55 & 21.60 & 16.66 & 17.76 & 18.65 & 15.31 & 16.24 & 17.05 & 1.35 \\
\hline No. of rows/ear & 11.52 & 11.75 & 11.88 & 10.99 & 11.25 & 11.39 & 10.67 & 10.91 & 11.07 & N.S. \\
\hline No. of kernels/row & 32.93 & 36.79 & 39.04 & 27.98 & 31.32 & 33.35 & 25.40 & 28.81 & 30.98 & 3.03 \\
\hline No. of kernels/ear & 384.67 & 436.43 & 467.30 & 312.63 & 356.33 & 383.30 & 276.04 & 318.39 & 346.46 & 8.85 \\
\hline Ear weight (g) & 163.39 & 190.17 & 208.12 & 127.70 & 149.18 & 163.99 & 100.05 & 118.05 & 130.76 & 10.65 \\
\hline Kernels weight/ear (g) & 124.71 & 148.83 & 165.92 & 96.75 & 115.81 & 129.21 & 73.14 & 88.43 & 99.68 & 8.99 \\
\hline Kernels shelling (\%) & 74.22 & 76.78 & 78.50 & 73.65 & 76.10 & 77.54 & 70.90 & 73.18 & 74.81 & N.S. \\
\hline 100-kernel weight (g) & 31.33 & 33.54 & 35.12 & 29.78 & 31.87 & 33.35 & 25.40 & 27.15 & 28.40 & 1.37 \\
\hline Ear yield/fed (kg) & 2976.69 & 3487.16 & 3932.72 & 2203.78 & 2642.06 & 2958.59 & 1805.31 & 2144.22 & 2444.19 & 262.11 \\
\hline Grain yield/fed (kg) & 2287.66 & 2743.75 & 3146.46 & 1682.58 & 2065.63 & 2345.06 & 1330.14 & 1617.88 & 1873.52 & 289.98 \\
\hline Stover yield/fed (kg) & 3813.47 & 4053.03 & 4268.03 & 3380.59 & 3658.56 & 3823.25 & 3730.41 & 3922.84 & 4143.84 & 265.96 \\
\hline Biological yield/fed (kg) & 6790.16 & 7540.19 & 8200.75 & 5584.38 & 6300.63 & 6781.84 & 5535.72 & 6067.06 & 6588.03 & 467.39 \\
\hline Harvest index $(\%)$ & 31.30 & 34.81 & 37.19 & 27.72 & 31.16 & 33.29 & 21.90 & 25.01 & 27.18 & 2.72 \\
\hline NUE (kg grains/kg N) & 20.40 & 20.69 & 21.27 & 15.50 & 16.39 & 17.00 & 12.11 & 13.16 & 13.43 & 1.92 \\
\hline KUE (kg grains/kg K) & -- & 19.01 & 17.89 & -- & 15.96 & 13.80 & -- & 11.99 & 11.32 & 1.70 \\
\hline Kernels nitrogen content (\%) & 1.935 & 1.984 & 2.023 & 1.793 & 1.873 & 1.912 & 1.769 & 1.822 & 1.859 & N.S. \\
\hline Kernels potassium content $(\%)$ & 0.506 & 0.553 & 0.578 & 0.467 & 0.507 & 0.524 & 0.420 & 0.462 & 0.488 & N.S. \\
\hline Kernels crude protein $(\%)$ & 12.09 & 12.40 & 12.65 & 11.21 & 11.71 & 11.95 & 11.06 & 11.39 & 11.62 & N.S. \\
\hline Nitrogen uptake/fed (kg) & 46.86 & 57.03 & 66.15 & 32.01 & 40.44 & 46.41 & 24.91 & 30.90 & 36.25 & 4.66 \\
\hline Protein yield/fed (kg) & 292.88 & 356.42 & 413.42 & 200.07 & 252.77 & 290.03 & 155.71 & 193.11 & 226.55 & 11.66 \\
\hline
\end{tabular}


Table 7: Mean values of agronomic traits of maize as affected by interaction between nitrogen and potassium fertilizer rates on in the combined analysis of 2015 and 2016

\begin{tabular}{|c|c|c|c|c|c|c|c|c|c|c|c|c|c|}
\hline \multirow{3}{*}{$\begin{array}{l}\text { Trait } \\
\text { Potassium }\left(\mathrm{kg} \mathrm{K}_{2} \mathrm{O} / \text { fed }\right) \\
\end{array}$} & \multicolumn{12}{|c|}{ Nitrogen (kg N/fed) } & \multirow{3}{*}{$\begin{array}{l}\text { L.S.D. } \\
\text { at } 5 \%\end{array}$} \\
\hline & \multicolumn{3}{|c|}{$\mathbf{0}$} & \multicolumn{3}{|c|}{50} & \multicolumn{3}{|c|}{100} & \multicolumn{3}{|c|}{150} & \\
\hline & $\mathbf{0}$ & 24 & 48 & $\mathbf{0}$ & 24 & 48 & $\mathbf{0}$ & 24 & 48 & $\mathbf{0}$ & 24 & 48 & \\
\hline Plant height (cm) & 220.83 & 232.88 & 241.13 & 257.04 & 263.75 & 268.08 & 277.75 & 283.50 & 286.63 & 292.46 & 295.96 & 299.29 & 8.44 \\
\hline Ear height (cm) & 107.92 & 113.83 & 117.88 & 125.83 & 128.88 & 130.96 & 135.25 & 138.50 & 140.00 & 142.92 & 144.67 & 146.21 & 7.02 \\
\hline No. of ears/fed (1000 ears) & 18.40 & 19.27 & 20.93 & 21.43 & 22.35 & 23.40 & 24.37 & 25.10 & 25.73 & 26.13 & 26.57 & 27.03 & 0.32 \\
\hline Ear diameter (cm) & 3.658 & 3.929 & 4.054 & 4.213 & 4.358 & 4.508 & 4.567 & 4.708 & 4.854 & 4.950 & 5.179 & 5.304 & N.S. \\
\hline Ear length (cm) & 12.14 & 13.58 & 15.29 & 16.47 & 17.58 & 18.25 & 18.71 & 19.91 & 20.53 & 20.97 & 21.67 & 22.32 & 1.56 \\
\hline No. of rows/ear & 10.23 & 10.50 & 10.60 & 10.73 & 11.06 & 11.28 & 11.42 & 11.62 & 11.77 & 11.88 & 12.05 & 12.13 & N.S. \\
\hline No. of kernels/row & 17.09 & 23.18 & 26.33 & 26.95 & 29.70 & 31.94 & 32.78 & 36.03 & 37.98 & 38.25 & 40.33 & 41.58 & 3.50 \\
\hline No. of kernels/ear & 175.95 & 244.74 & 280.45 & 290.46 & 329.81 & 361.35 & 375.83 & 419.86 & 448.39 & 455.57 & 487.12 & 505.89 & 10.22 \\
\hline Ear weight (g) & 58.07 & 85.99 & 104.52 & 112.55 & 132.79 & 147.41 & 152.27 & 176.66 & 195.67 & 198.63 & 214.42 & 222.90 & 12.30 \\
\hline Kernels weight/ear (g) & 38.23 & 59.11 & 73.21 & 78.93 & 96.74 & 111.73 & 116.41 & 139.95 & 156.94 & 159.23 & 174.96 & 184.53 & 10.38 \\
\hline Kernels shelling (\%) & 65.68 & 68.47 & 69.75 & 69.83 & 72.53 & 75.48 & 76.24 & 78.99 & 79.97 & 79.95 & 81.41 & 82.60 & 2.30 \\
\hline 100-kernel weight (g) & 21.73 & 24.20 & 26.21 & 27.29 & 29.47 & 31.05 & 31.14 & 33.54 & 35.16 & 35.20 & 36.19 & 36.73 & 1.58 \\
\hline Ear yield/fed (kg) & 812.54 & 1251.88 & 1645.58 & 1813.00 & 2222.67 & 2582.00 & 2790.21 & 3327.38 & 3772.79 & 3898.63 & 4229.33 & 4446.96 & 302.66 \\
\hline Grain yield/fed (kg) & 535.05 & 860.88 & 1153.14 & 1272.33 & 1620.59 & 1958.33 & 2133.80 & 2636.80 & 3026.74 & 3126.01 & 3451.42 & 3681.83 & 334.84 \\
\hline Stover yield/fed (kg) & 2083.54 & 2310.71 & 2646.63 & 3358.71 & 3664.63 & 3797.25 & 4307.17 & 4574.00 & 4713.75 & 4816.54 & 4963.25 & 5155.88 & 307.10 \\
\hline Biological yield/fed (kg) & 2896.08 & 3562.58 & 4292.21 & 5171.71 & 5887.29 & 6379.25 & 7097.38 & 7901.38 & 8486.54 & 8715.17 & 9192.58 & 9602.83 & 539.70 \\
\hline Harvest index (\%) & 18.28 & 23.85 & 26.56 & 24.33 & 27.19 & 30.32 & 29.74 & 33.03 & 35.30 & 35.55 & 37.24 & 38.04 & 3.14 \\
\hline NUE (kg grains/kg N) & -- & -- & -- & 14.75 & 15.20 & 16.10 & 15.99 & 17.77 & 18.74 & 17.28 & 17.27 & 16.86 & 2.22 \\
\hline KUE (kg grains/kg K) & -- & 13.58 & 12.88 & -- & 14.52 & 14.30 & -- & 20.96 & 18.61 & -- & 13.56 & 11.58 & 1.96 \\
\hline Kernels nitrogen content (\%) & 1.551 & 1.628 & 1.678 & 1.763 & 1.812 & 1.850 & 1.933 & 2.000 & 2.042 & 2.082 & 2.133 & 2.157 & 0.164 \\
\hline Kernels potassium content (\%) & 0.433 & 0.473 & 0.496 & 0.455 & 0.500 & 0.519 & 0.477 & 0.518 & 0.541 & 0.493 & 0.538 & 0.563 & N.S. \\
\hline Kernels crude protein (\%) & 9.69 & 10.17 & 10.48 & 11.02 & 11.32 & 11.56 & 12.08 & 12.50 & 12.76 & 13.01 & 13.33 & 13.48 & 0.42 \\
\hline Nitrogen uptake/fed (kg) & 8.39 & 14.10 & 19.46 & 22.69 & 29.66 & 36.56 & 41.64 & 53.24 & 62.42 & 65.67 & 74.15 & 79.96 & 5.38 \\
\hline Protein yield/fed (kg) & 52.41 & 88.10 & 121.64 & 141.83 & 185.41 & 228.49 & 260.22 & 332.78 & 390.12 & 410.42 & 463.45 & 499.74 & 13.46 \\
\hline
\end{tabular}




\section{7) Effect of interaction between water stress, nitrogen and potassium fertilizer rates:}

Results in Tables 8, 9 and 10 showed significant interaction effect between water stress treatments (normal irrigation, skipping the $2^{\text {nd }}$ irrigation and skipping the $5^{\text {th }}$ irrigation), nitrogen fertilizer rates $(0$, 50,100 and $150 \mathrm{~kg} \mathrm{~N} / \mathrm{fed}$ ) and potassium fertilizer rates $\left(0,24\right.$ and $\left.48 \mathrm{~kg} \mathrm{~K}_{2} \mathrm{O} / \mathrm{fed}\right)$ under study on mean values of plant height, No. of ears/fed, No. of kernels/ear, ear weight $(\mathrm{g})$, kernels weight/ear $(\mathrm{g})$, ear yield/fed $(\mathrm{kg})$, grain yield/fed $(\mathrm{kg})$, stover yield/fed $(\mathrm{kg})$, biological yield/fed $(\mathrm{kg})$, nitrogen uptake/fed $(\mathrm{kg})$ and protein yield/fed $(\mathrm{kg})$ of maize. While, mean values of ear height $(\mathrm{cm})$, ear length $(\mathrm{cm})$, ear diameter $(\mathrm{cm})$, No. of rows/ear, No. of kernels/row, kernels shelling (\%), 100-kernel weight $(\mathrm{g})$, harvest index (\%), NUE ( $\mathrm{kg}$ grains $/ \mathrm{kg} \mathrm{N}), \mathrm{KUE}(\mathrm{kg}$ grains $/ \mathrm{kg}$ $\mathrm{K})$, kernels nitrogen content (\%), kernels potassium content $(\%)$ and kernels crude protein $(\%)$ were not significantly affected by interaction in the combined analysis of both seasons. The maximum mean values of plant height $(314.25 \mathrm{~cm})$, No. of ears/fed $(27.90$ thousand ears), No. of kernels/ear (589.56 kernels), ear weight (277.04 g), kernels weight/ear (232.04 g), ear yield/fed $(5469.00 \mathrm{~kg})$, grain yield/fed (4582.23 $\mathrm{kg})$, stover yield/fed $(5423.13 \mathrm{~kg})$, biological yield/fed $(10892.13 \mathrm{~kg})$, nitrogen uptake/fed (103.99 $\mathrm{kg}$ ) and protein yield/fed $(649.93 \mathrm{~kg})$ which were obtained by planting maize with normal irrigation treatment under soil fertilized by $150 \mathrm{~kg} \mathrm{~N} /$ fed and 48 $\mathrm{kg} \mathrm{K}_{2} \mathrm{O} / \mathrm{fed}$. Planting maize under water stress by skipping the $2^{\text {nd }}$ irrigation without soil fertilized by nitrogen and potassium gave the lowest mean values of plant height $(198.25 \mathrm{~cm})$, No. of ears/fed $(17.10$ thousand ears), stover yield/fed (1842.75 kg) and biological yield/fed $(2575.63 \mathrm{~kg})$. Results recorded that sowing maize under water stress by skipping the $5^{\text {th }}$ irrigation without nitrogen and potassium add gave the minimum mean values of No. of kernels/ear (142.71 kernels), ear weight (42.46 g), kernels weight/ear $(27.13 \mathrm{~g})$, ear yield/fed $(603.25 \mathrm{~kg})$, grain yield/fed $(385.52 \mathrm{~kg})$, nitrogen uptake/fed $(5.87 \mathrm{~kg})$ and protein yield/fed $(36.67 \mathrm{~kg})$. Results agree with those reported byWaraichet al. 2011 and Paschalidiset al. 2015.

\section{Conclusion:}

From the obtained results of this study it could be concluded that planting maize under full irrigation with soil fertilized by $150 \mathrm{~kg} \mathrm{~N}+48 \mathrm{~kg} \mathrm{~K}_{2} \mathrm{O} / \mathrm{fed}$ in order to maximizing its productivity. 
Table 8: Mean values of plant height $(\mathrm{cm})$, ear height $(\mathrm{cm})$, No. of ears/fed, ear diameter $(\mathrm{cm})$, ear length $(\mathrm{cm})$, No. of rows/ear, No. of kernels/row and No. of kernels/ear of maize as affected by interaction between water stress, nitrogen fertilizer rates and potassium fertilizer rates in the combined analysis of 2015 and 2016 seasons.

\begin{tabular}{|c|c|c|c|c|c|c|c|c|c|c|}
\hline Treatment & & Trait & $\begin{array}{c}\text { Plant } \\
\text { height } \\
\text { (cm) }\end{array}$ & $\begin{array}{c}\text { Ear } \\
\text { height } \\
(\mathbf{c m})\end{array}$ & $\begin{array}{c}\begin{array}{c}\text { No. of } \\
\text { ears/fed } \\
(1000 \\
\text { ears })\end{array} \\
\end{array}$ & $\begin{array}{c}\text { Ear } \\
\text { diameter } \\
(\mathbf{c m})\end{array}$ & $\begin{array}{c}\text { Ear } \\
\text { length } \\
(\mathrm{cm})\end{array}$ & $\begin{array}{c}\text { No. of } \\
\text { rows } \\
\text { lear }\end{array}$ & $\begin{array}{c}\text { No. of } \\
\text { kernels } \\
\text { /row }\end{array}$ & $\begin{array}{l}\text { No. of } \\
\text { kernels } \\
\text { /ear }\end{array}$ \\
\hline \multicolumn{11}{|c|}{ Water stress X Nitrogen (kg N/fed) X Potassium (kg K2 O/fed) } \\
\hline \multirow{12}{*}{$\begin{array}{l}\text { Normal } \\
\text { irrigation }\end{array}$} & \multirow{3}{*}{$\mathbf{0}$} & $\mathbf{0}$ & 233.88 & 117.50 & 19.60 & 3.938 & 13.43 & 10.71 & 20.38 & 218.59 \\
\hline & & 24 & 244.63 & 122.88 & 20.50 & 4.175 & 15.08 & 10.95 & 27.46 & 300.95 \\
\hline & & 48 & 254.50 & 127.88 & 22.30 & 4.238 & 17.21 & 11.08 & 30.48 & 337.70 \\
\hline & \multirow{3}{*}{50} & $\mathbf{0}$ & 275.25 & 138.50 & 22.70 & 4.425 & 18.48 & 11.19 & 31.15 & 348.69 \\
\hline & & 24 & 279.63 & 140.38 & 23.50 & 4.575 & 20.06 & 11.50 & 34.08 & 392.13 \\
\hline & & 48 & 283.50 & 142.13 & 24.80 & 4.725 & 20.78 & 11.64 & 36.36 & 423.44 \\
\hline & \multirow{3}{*}{100} & $\mathbf{0}$ & 295.38 & 148.38 & 25.50 & 4.788 & 21.23 & 11.85 & 37.29 & 442.20 \\
\hline & & 24 & 301.25 & 151.00 & 26.10 & 4.925 & 22.49 & 12.04 & 40.33 & 485.61 \\
\hline & & 48 & 304.25 & 152.63 & 26.80 & 5.088 & 23.16 & 12.20 & 42.49 & 518.50 \\
\hline & \multirow{3}{*}{150} & 0 & 309.13 & 155.00 & 26.90 & 5.200 & 23.85 & 12.34 & 42.89 & 529.20 \\
\hline & & 24 & 312.25 & 156.63 & 27.30 & 5.438 & 24.58 & 12.51 & 45.31 & 567.02 \\
\hline & & 48 & 314.25 & 157.75 & 27.90 & 5.550 & 25.24 & 12.59 & 46.84 & 589.56 \\
\hline \multirow{12}{*}{$\begin{array}{l}\text { Skipping } \\
\text { the } 2^{\text {nd }} \\
\text { irrigation }\end{array}$} & \multirow{3}{*}{$\mathbf{0}$} & 0 & 198.25 & 92.38 & 17.10 & 3.663 & 11.94 & 10.15 & 16.39 & 166.55 \\
\hline & & 24 & 210.38 & 98.25 & 18.40 & 3.988 & 13.36 & 10.43 & 22.45 & 234.31 \\
\hline & & 48 & 217.88 & 101.75 & 19.60 & 4.100 & 14.96 & 10.55 & 25.49 & 269.14 \\
\hline & \multirow{3}{*}{50} & $\mathbf{0}$ & 223.63 & 104.38 & 20.50 & 4.288 & 16.18 & 10.64 & 26.14 & 278.29 \\
\hline & & 24 & 234.00 & 109.00 & 21.45 & 4.425 & 17.04 & 11.03 & 28.79 & 317.57 \\
\hline & & 48 & 239.75 & 111.88 & 22.30 & 4.625 & 17.68 & 11.24 & 31.35 & 352.58 \\
\hline & \multirow{3}{*}{100} & $\mathbf{0}$ & 243.88 & 113.63 & 23.20 & 4.688 & 18.09 & 11.39 & 32.26 & 367.68 \\
\hline & & 24 & 249.38 & 116.25 & 24.30 & 4.838 & 19.53 & 11.58 & 35.50 & 411.18 \\
\hline & & 48 & 254.38 & 118.38 & 24.70 & 4.988 & 20.13 & 11.71 & 37.01 & 433.69 \\
\hline & \multirow{3}{*}{150} & $\mathbf{0}$ & 262.50 & 122.38 & 25.20 & 5.125 & 20.44 & 11.80 & 37.11 & 438.03 \\
\hline & & 24 & 267.50 & 124.75 & 25.90 & 5.375 & 21.11 & 11.99 & 38.55 & 462.26 \\
\hline & & 48 & 272.50 & 127.00 & 26.30 & 5.525 & 21.83 & 12.08 & 39.56 & 477.81 \\
\hline \multirow{12}{*}{$\begin{array}{l}\text { Skipping } \\
\text { the } 5^{\text {th }} \\
\text { irrigation }\end{array}$} & \multirow{3}{*}{$\mathbf{0}$} & $\mathbf{0}$ & 230.38 & 113.88 & 18.50 & 3.375 & 11.05 & 9.81 & 14.51 & 142.71 \\
\hline & & 24 & 243.63 & 120.38 & 18.90 & 3.625 & 12.29 & 10.13 & 19.63 & 198.97 \\
\hline & & 48 & 251.00 & 124.00 & 20.90 & 3.825 & 13.69 & 10.18 & 23.03 & 234.51 \\
\hline & \multirow{3}{*}{50} & $\mathbf{0}$ & 272.25 & 134.63 & 21.10 & 3.925 & 14.76 & 10.36 & 23.56 & 244.40 \\
\hline & & 24 & 277.63 & 137.25 & 22.10 & 4.075 & 15.63 & 10.65 & 26.24 & 279.72 \\
\hline & & 48 & 281.00 & 138.88 & 23.10 & 4.175 & 16.29 & 10.95 & 28.11 & 308.03 \\
\hline & \multirow{3}{*}{100} & $\mathbf{0}$ & 294.00 & 143.75 & 24.40 & 4.225 & 16.81 & 11.03 & 28.79 & 317.61 \\
\hline & & 24 & 299.88 & 148.25 & 24.90 & 4.363 & 17.73 & 11.24 & 32.26 & 362.79 \\
\hline & & 48 & 301.25 & 149.00 & 25.70 & 4.488 & 18.31 & 11.40 & 34.45 & 392.99 \\
\hline & \multirow{3}{*}{150} & $\mathbf{0}$ & 305.75 & 151.38 & 26.30 & 4.525 & 18.63 & 11.49 & 34.75 & 399.46 \\
\hline & & 24 & 308.13 & 152.63 & 26.50 & 4.725 & 19.33 & 11.64 & 37.11 & 432.09 \\
\hline & & 48 & 311.13 & 153.88 & 26.90 & 4.838 & 19.90 & 11.74 & 38.35 & 450.31 \\
\hline L.S.D. & at $5 \%$ & & 14.62 & N.S. & 0.55 & N.S. & N.S. & N.S. & N.S. & 17.70 \\
\hline
\end{tabular}


Table 9: Mean values of ear weight (g), kernels weight/ear (g), kernels shelling (\%), 100-kernel weight (g), ear yield/fed $(\mathrm{kg})$, grain yield/fed $(\mathrm{kg})$, stover yield/fed $(\mathrm{kg})$ and biological yield/fed $(\mathrm{kg})$ of maize as affected by interaction between water stress, nitrogen fertilizer rates and potassium fertilizer rates in the combined analysis of 2015 and 2016 seasons.

\begin{tabular}{|c|c|c|c|c|c|c|c|c|c|c|}
\hline Treatment & & Trait & $\begin{array}{c}\text { Ear } \\
\text { weight } \\
\text { (g) }\end{array}$ & $\begin{array}{c}\text { Kernels } \\
\text { weight } \\
\text { /ear (g) }\end{array}$ & $\begin{array}{c}\text { Kernels } \\
\text { shelling } \\
(\%)\end{array}$ & $\begin{array}{l}\text { 100-kernel } \\
\text { weight (g) }\end{array}$ & $\begin{array}{c}\text { Ear } \\
\text { yield/fed } \\
(\mathbf{k g}) \\
\end{array}$ & $\begin{array}{c}\text { Grain } \\
\text { yield/fed } \\
(\mathbf{k g})\end{array}$ & $\begin{array}{c}\text { Stover } \\
\text { yield/fed } \\
(\mathrm{kg})\end{array}$ & $\begin{array}{c}\text { Biological } \\
\text { yield/fed } \\
(\mathrm{kg})\end{array}$ \\
\hline \multicolumn{11}{|c|}{ Water stress X Nitrogen (kg N/fed) X Potassium (kg K $\left.\mathrm{K}_{2} \mathrm{O} / \mathrm{fed}\right)$} \\
\hline \multirow{12}{*}{$\begin{array}{c}\text { Normal } \\
\text { irrigation }\end{array}$} & \multirow{3}{*}{$\mathbf{0}$} & 0 & 76.40 & 50.71 & 66.47 & 23.53 & 1101.50 & 731.48 & 2224.00 & 3325.50 \\
\hline & & 24 & 111.49 & 77.69 & 69.70 & 26.25 & 1683.25 & 1173.16 & 2513.63 & 4196.88 \\
\hline & & 48 & 132.55 & 94.60 & 71.39 & 28.46 & 2177.88 & 1554.54 & 2858.75 & 5036.63 \\
\hline & \multirow{3}{*}{50} & $\mathbf{0}$ & 141.91 & 101.61 & 71.63 & 29.64 & 2373.88 & 1700.12 & 3553.38 & 5927.25 \\
\hline & & 24 & 165.87 & 123.60 & 74.54 & 32.02 & 2872.00 & 2140.46 & 3742.38 & 6614.38 \\
\hline & & 48 & 182.26 & 141.09 & 77.41 & 33.76 & 3330.63 & 2577.92 & 3906.75 & 7237.38 \\
\hline & \multirow{4}{*}{100} & $\mathbf{0}$ & 190.32 & 147.25 & 77.41 & 33.86 & 3574.63 & 2766.79 & 4483.25 & 8057.88 \\
\hline & & 24 & 217.16 & 174.40 & 80.33 & 36.49 & 4177.00 & 3355.20 & 4747.13 & 8924.13 \\
\hline & & 48 & 240.64 & 195.96 & 81.44 & 38.27 & 4753.38 & 3871.16 & 4883.50 & 9636.88 \\
\hline & & $\mathbf{0}$ & 244.93 & 199.25 & 81.36 & 38.31 & 4856.75 & 3952.27 & 4993.25 & 9850.00 \\
\hline & \multirow[t]{3}{*}{150} & 24 & 266.18 & 219.65 & 82.53 & 39.40 & 5216.38 & 4306.16 & 5209.00 & 10425.38 \\
\hline & & 48 & 277.04 & 232.04 & 83.77 & 39.99 & 5469.00 & 4582.23 & 5423.13 & 10892.13 \\
\hline \multirow{12}{*}{$\begin{array}{l}\text { Skipping } \\
\text { the } 2^{\text {nd }} \\
\text { irrigation }\end{array}$} & & 0 & 55.36 & 36.85 & 66.60 & 22.42 & 732.88 & 488.16 & 1842.75 & 2575.63 \\
\hline & \multirow[t]{3}{*}{$\mathbf{0}$} & 24 & 83.17 & 57.68 & 69.41 & 24.98 & 1165.75 & 808.53 & 2034.88 & 3200.63 \\
\hline & & 48 & 101.74 & 71.59 & 70.42 & 27.06 & 1510.25 & 1062.84 & 2359.88 & 3870.13 \\
\hline & & $\mathbf{0}$ & 109.72 & 77.19 & 70.41 & 28.18 & 1699.50 & 1195.96 & 3078.25 & 4777.75 \\
\hline & \multirow[t]{2}{*}{50} & 24 & 130.41 & 95.23 & 73.09 & 30.43 & 2104.25 & 1537.88 & 3567.88 & 5672.13 \\
\hline & & 48 & 146.75 & 111.31 & 75.90 & 32.07 & 2456.38 & 1864.44 & 3646.00 & 6102.38 \\
\hline & \multirow{4}{*}{100} & $\mathbf{0}$ & 151.08 & 116.29 & 77.03 & 32.16 & 2662.50 & 2050.23 & 4051.38 & 6713.88 \\
\hline & & 24 & 175.93 & 140.20 & 79.75 & 34.65 & 3234.13 & 2578.24 & 4345.13 & 7579.25 \\
\hline & & 48 & 192.88 & 155.29 & 80.55 & 36.33 & 3597.13 & 2896.71 & 4471.38 & 8068.50 \\
\hline & & $\mathbf{0}$ & 194.65 & 156.68 & 80.56 & & 3720.25 & 2995.99 & 4550.00 & 8270.25 \\
\hline & \multirow[t]{3}{*}{150} & 24 & 207.21 & 170.13 & 82.16 & 37.40 & 4064.13 & 3337.88 & 4686.38 & 8750.50 \\
\hline & & 48 & 214.60 & 178.65 & 83.30 & 37.96 & 4270.63 & 3556.25 & 4815.75 & 9086.38 \\
\hline \multirow{12}{*}{$\begin{array}{l}\text { Skipping } \\
\text { the } 5^{\text {th }} \\
\text { irrigation }\end{array}$} & & 0 & 42.46 & 27.13 & 63.95 & 19.23 & 603.25 & 385.52 & 2183.88 & 2787.13 \\
\hline & \multirow[t]{3}{*}{$\mathbf{0}$} & 24 & 63.32 & 41.96 & 66.30 & 21.38 & 906.63 & 600.93 & 2383.63 & 3290.25 \\
\hline & & 48 & 79.26 & 53.44 & 67.45 & 23.12 & 1248.63 & 842.04 & 2721.25 & 3969.88 \\
\hline & & $\mathbf{0}$ & 86.03 & 58.00 & 67.45 & 24.06 & 1365.63 & 920.90 & 3444.50 & 4810.13 \\
\hline & \multirow[t]{2}{*}{50} & 24 & 102.09 & 71.40 & 69.96 & 25.95 & 1691.75 & 1183.41 & 3683.63 & 5375.38 \\
\hline & & 48 & 113.22 & 82.79 & 73.14 & 27.32 & 1959.00 & 1432.64 & 3839.00 & 5798.00 \\
\hline & \multirow{3}{*}{100} & $\mathbf{0}$ & 115.40 & 85.69 & 74.29 & 27.40 & 2133.50 & 1584.37 & 4386.88 & 6520.38 \\
\hline & & 24 & 136.90 & 105.25 & 76.91 & 29.48 & 2571.00 & 1976.95 & 4629.75 & 7200.75 \\
\hline & & 48 & 153.49 & 119.58 & 77.92 & 30.89 & 2967.88 & 2312.36 & 4786.38 & 7754.25 \\
\hline & \multirow{3}{*}{150} & 0 & 156.33 & 121.76 & 77.92 & 30.92 & 3118.88 & 2429.78 & 4906.38 & 8025.25 \\
\hline & & 24 & 169.89 & 135.11 & 79.55 & 31.78 & 3407.50 & 2710.21 & 4994.38 & 8401.88 \\
\hline & & 48 & 177.05 & 142.91 & 80.73 & 32.25 & 3601.25 & 2907.03 & 5228.75 & 8830.00 \\
\hline L.S.D. & at $5 \%$ & & 21.30 & 17.98 & N.S. & N.S. & 524.22 & 579.96 & 531.91 & 934.79 \\
\hline
\end{tabular}


Table 10: Mean values of harvest index (\%), NUE (kg grains/kg N), KUE (kg grains/kg K), kernels nitrogen content $(\%)$,kernels potassium content $(\%)$, kernels crude protein $(\%)$, nitrogen uptake/fed $(\mathrm{kg})$ and protein yield/fed $(\mathrm{kg})$ of maize as affected by interaction between water stress, nitrogen fertilizer rates and potassium fertilizer rates in the combined analysis of 2015 and 2016 seasons.

\begin{tabular}{|c|c|c|c|c|c|c|c|c|c|c|}
\hline Treatment & & Trait & $\begin{array}{c}\text { Harvest } \\
\text { index } \\
(\%)\end{array}$ & $\begin{array}{c}\text { NUE } \\
(\text { kg grains } \\
\text { /kg N) }\end{array}$ & $\begin{array}{c}\text { KUE } \\
\text { (kg grains } \\
\text { /kg K) }\end{array}$ & $\begin{array}{c}\text { Kernels } \\
\text { nitrogen } \\
\text { content } \\
(\%)\end{array}$ & $\begin{array}{c}\text { Kernels } \\
\text { potassium } \\
\text { content } \\
(\%)\end{array}$ & $\begin{array}{c}\text { Kernels } \\
\text { crude } \\
\text { protein } \\
(\%)\end{array}$ & $\begin{array}{c}\text { Nitrogen } \\
\text { uptake } \\
\text { /fed (kg) }\end{array}$ & $\begin{array}{c}\text { Protein } \\
\text { yield/fed } \\
\text { (kg) }\end{array}$ \\
\hline \multicolumn{11}{|c|}{ Water stress X Nitrogen (kg N/fed) X Potassium $\left(\mathrm{kg} \mathrm{K}_{2} \mathrm{O} / \mathrm{fed}\right)$} \\
\hline \multirow{12}{*}{$\begin{array}{l}\text { Normal } \\
\text { irrigation }\end{array}$} & \multirow{3}{*}{$\mathbf{0}$} & 0 & 22.03 & -- & -- & 1.618 & 0.481 & 10.11 & 11.85 & 74.05 \\
\hline & & 24 & 27.98 & -- & 18.41 & 1.668 & 0.518 & 10.42 & 19.58 & 122.36 \\
\hline & & 48 & 30.93 & -- & 17.15 & 1.718 & 0.544 & 10.73 & 26.71 & 166.93 \\
\hline & \multirow{3}{*}{50} & $\mathbf{0}$ & 28.71 & 19.38 & -- & 1.874 & 0.498 & 11.71 & 31.87 & 199.17 \\
\hline & & 24 & 32.38 & 19.35 & 18.35 & 1.909 & 0.546 & 11.93 & 40.86 & 255.38 \\
\hline & & 48 & 35.64 & 20.47 & 18.29 & 1.944 & 0.573 & 12.15 & 50.10 & 313.15 \\
\hline & \multirow{3}{*}{100} & $\mathbf{0}$ & 34.35 & 20.36 & -- & 2.039 & 0.518 & 12.74 & 56.41 & 352.58 \\
\hline & & 24 & 37.60 & 21.83 & 24.52 & 2.109 & 0.566 & 13.18 & 70.77 & 442.30 \\
\hline & & 48 & 40.18 & 23.17 & 23.01 & 2.164 & 0.593 & 13.52 & 83.78 & 523.64 \\
\hline & \multirow{3}{*}{150} & $\mathbf{0}$ & 40.13 & 21.47 & -- & 2.209 & 0.528 & 13.80 & 87.32 & 545.74 \\
\hline & & 24 & 41.29 & 20.89 & 14.75 & 2.250 & 0.583 & 14.06 & 96.90 & 605.64 \\
\hline & & 48 & 42.03 & 20.19 & 13.13 & 2.269 & 0.603 & 14.18 & 103.99 & 649.93 \\
\hline \multirow{12}{*}{$\begin{array}{l}\text { Skipping } \\
\text { the } 2^{\text {nd }} \\
\text { irrigation }\end{array}$} & \multirow{3}{*}{$\mathbf{0}$} & $\mathbf{0}$ & 18.96 & -- & -- & 1.518 & 0.430 & 9.48 & 7.44 & 46.51 \\
\hline & & 24 & 25.28 & -- & 13.36 & 1.618 & 0.466 & 10.11 & 13.10 & 81.87 \\
\hline & & 48 & 27.49 & -- & 11.98 & 1.688 & 0.489 & 10.55 & 17.95 & 112.21 \\
\hline & \multirow{3}{*}{50} & $\mathbf{0}$ & 25.12 & 14.16 & -- & 1.718 & 0.450 & 10.73 & 20.56 & 128.51 \\
\hline & & 24 & 27.17 & 14.59 & 14.25 & 1.798 & 0.499 & 11.23 & 27.65 & 172.80 \\
\hline & & 48 & 30.61 & 16.04 & 13.93 & 1.833 & 0.513 & 11.45 & 34.16 & 213.53 \\
\hline & \multirow{3}{*}{100} & $\mathbf{0}$ & 30.56 & 15.63 & -- & 1.899 & 0.480 & 11.87 & 38.95 & 243.41 \\
\hline & & 24 & 34.03 & 17.70 & 22.01 & 1.989 & 0.519 & 12.43 & 51.29 & 320.56 \\
\hline & & 48 & 35.91 & 18.34 & 17.64 & 2.019 & 0.533 & 12.62 & 58.49 & 365.58 \\
\hline & \multirow{3}{*}{150} & $\mathbf{0}$ & 36.24 & 16.72 & -- & 2.039 & 0.509 & 12.74 & 61.10 & 381.85 \\
\hline & & 24 & 38.16 & 16.87 & 14.25 & 2.089 & 0.545 & 13.05 & 69.74 & 435.87 \\
\hline & & 48 & 39.15 & 16.63 & 11.68 & 2.109 & 0.561 & 13.18 & 75.01 & 468.82 \\
\hline \multirow{12}{*}{$\begin{array}{l}\text { Skipping } \\
\text { the } 5^{\text {th }} \\
\text { irrigation }\end{array}$} & \multirow{3}{*}{$\mathbf{0}$} & $\mathbf{0}$ & 13.85 & -- & -- & 1.518 & 0.389 & 9.48 & 5.87 & 36.67 \\
\hline & & 24 & 18.28 & -- & 8.98 & 1.598 & 0.436 & 9.98 & 9.61 & 60.08 \\
\hline & & 48 & 21.26 & -- & 9.51 & 1.628 & 0.456 & 10.17 & 13.73 & 85.79 \\
\hline & \multirow{3}{*}{$\mathbf{5 0}$} & $\mathbf{0}$ & 19.16 & 10.71 & -- & 1.698 & 0.416 & 10.61 & 15.65 & 97.81 \\
\hline & & 24 & 22.03 & 11.65 & 10.94 & 1.729 & 0.456 & 10.80 & 20.49 & 128.04 \\
\hline & & 48 & 24.72 & 11.82 & 10.66 & 1.773 & 0.473 & 11.08 & 25.41 & 158.78 \\
\hline & \multirow{3}{*}{100} & $\mathbf{0}$ & 24.30 & 11.99 & -- & 1.863 & 0.433 & 11.64 & 29.55 & 184.68 \\
\hline & & 24 & 27.45 & 13.77 & 16.37 & 1.904 & 0.470 & 11.90 & 37.67 & 235.47 \\
\hline & & 48 & 29.82 & 14.71 & 15.17 & 1.944 & 0.499 & 12.15 & 44.98 & 281.15 \\
\hline & \multirow{3}{*}{150} & $\mathbf{0}$ & 30.28 & 13.63 & -- & 1.999 & 0.443 & 12.49 & 48.59 & 303.67 \\
\hline & & 24 & 32.27 & 14.07 & 11.68 & 2.059 & 0.486 & 12.87 & 55.82 & 348.85 \\
\hline & & 48 & 32.93 & 13.77 & 9.95 & 2.094 & 0.525 & 13.09 & 60.88 & 380.48 \\
\hline L.S.D & at $5 \%$ & & N.S. & N.S. & N.S. & N.S. & N.S. & N.S. & 9.32 & 23.31 \\
\hline
\end{tabular}




\section{References:}

A.O.A.C. (1990).Official Methods of Analysis Association of Official Analysis Chemists, $13^{\text {th }}$ Ed., Washington, D. C., U. S. A.

Ahmad, M. H.; R. Ahmad; A. Ali; M. Ishaque and A. Rehman (2012). Potassium use efficiency of maize hybrids. J. Anim. Plant Sci., 22 (3): 728732.

Al-Kaisi M. M. and X. Yin (2003). Effects of nitrogen rate, irrigation rate and plant population on corn yield and water use efficiency. Agron. J. 94: 1475-1482.

Amanullah; A. Iqbal; Irfanullah and Z. Hidayat (2016).Potassium management for improving growth and grain yield of maize (Zea mays, L.) under moisture stress condition. Sci. Rep., 6, 34627: 1-12.

Aslam, M.; M. S. I. Zamir; I. Afzal; M. Yaseen; M. Mubeen and A. Shoaib (2013). Drought stress, its effect on maize production and development of drought tolerance through potassium application.Cercet.Agron.Mold., 46, 99-114.

Azab, E. (2016). Effect of water stress and biological fertilization on maize growth, chemical and productivity in calcareous soil. Am. J. Plant Physiol., 11 (1-3): 1-11.

Barbar, S. A. (1976). Efficient fertilizer use In: Patterson. F. L. Ed. Agronomic Research for Food.American Society of Agronomy special Publication, 26, Madison, USA. Pp. 13-29.

Barnabas, B.; K. Jager and A. Feher (2008). The effect of drought and heat stress on reproductive processes in cereals. Plant Cell Environ., 31 (1): 11-38.

Bruns, H. A. and M. W. Ebelhar (2006).Nutrient uptake of maize affected by nitrogen and potassium fertility in a humid subtropical environment.Commun. Soil Sci. Plant Anal., 37: 275-293.

Cakir, R. (2004).Effect of water stress at different development stages on vegetative and reproductive growth of corn. Field Crops Res., 89 (9): 1-16.

Cakmak, I. (2005). The role of potassium in alleviating detrimental effects of abiotic stresses in plants. J. Plant Nutr. Soil Sci., 168 (5): 521530.

Cattivelli, L.; F. Rizza; F. W. Badeck; E. Mazzucotelli and A. M. Mastrangelo (2008). Drought tolerance improvement in crop plants: An integrated view from breeding to genomic. Field Crops Res., 105: 1-14.

Derby, N. E.; D.D. Steele; J. Terpstra; R. E. Knighton and F. X. M. Casey (2005).Interactions of nitrogen, weather, soil, and irrigation on corn yield. Agron. J. 97 (5):13421351.
El-Dissoky, R. A.; E, M. Morsy and M. A. ElShazly (2013). Beneficial effect of potassium fertilization and yeast strains on maize plants grown on salt affected soil. J. Soil Sci. Agric. Eng., Mansoura Univ., 4 (9): 827 - 842.

El-Gedwy, E. M. M.; M. R. Gomaa and S. A. H. Allam (2011). Maize yield potential as affected by organic \& mineral nitrogen and tillage. LAP Lambert Academic Publishing, ISBN 978-38473-0842-3, paperback, 286 PP.

El-Habbak, A. K.; H. R. El-Deepah; M. I. Salwau and N. Kh. El-Gizawy (2019).Effect of organic, inorganic and nano fertilizers on agronomic traits of maize.of Agric. Sci., Moshtohor, 57 (1): 11-20.

El-Hosary, A. A.; G. Y. Hammam; E. M. M. ElGedwy and M. E. Sidi (2019 a).Response of white maize hybrids to plant densities and nitrogen fertilizer rates. Annals of Agric. Sci., Moshtohor, 57 (2): 333-350.

El-Hosary, A. A.; G. Y. Hammam; E. M. M. ElGedwy; A. A. A. El-Hosary and M. E. Sidi (2019 b). Response of white maize hybrids to various nitrogen fertilizer rates in Qalyubia, Egypt. Bioscience Res., 16 (3): 2475-2485.

Esfandiari, E.; M, R. Shakiba; S. A. Mahboob; H. Alyari and S. Shahabivand (2008). The effect of water stress on the antioxidant content, protective enzyme activities, proline content and lipid peroxidation in wheat seedling. Pak. J. Biol. Sci., 11: $1916-1922$

Freed, R. D. (1991).MSTATC Microcomputer Statistical Program.Michigan State University, East Lansing, Michigan, USA.

Gharibi, A. I. S.; G. Y. M. Hammam; M. E. M. Salwau; S. A. H. Allam and E. M. M. ElGedwy (2016).Response of maize yield to nitrogen fertilization and foliar spray by some microelements. J. Plant Production, Mansoura Univ., 7 (5): 455-463.

Gheysari, M.; H. W. Loescher; S. H. Sadeghi; S. M. Mirlatifi; M. J. Zareian and G. Hoogenboom (2015). Water-Yield Relations and Water Use Efficiency of Maize Under Nitrogen Fertigation for Semiarid Environments: Experiment and Synthesis. Adv. Agro., 130: 175229.

Gomez, K. A. and A. A. Gomez (1984).Statistical Procedures for Agricultural Research. 2 $2^{\text {nd }}$, (ed). John Wiley and Sons, NY, U.S.A.

Haghjoo, M.; F. P. Nezhad; E. Amiri; S. Vazan and M. M. K. Manesh (2013). Maize response to nitrogen and irrigation regimes.Am-Euras. J. Agric. \& Environ. Sci., 13 (5): 639-646.

Hall, M. A. (1978).Plant structure, function and adaptation. ELBS and Macmillan, USA., PP: 157.

Hall, M. A. (1982). Plant structure, function and adaptation. Macmillan, USA., ISBN: 9780333344552, PP: 192-195. 
Hammad, H. M.; A. Ahmad; F. Abbas; W. Farhad; B. C. Cordoba and G. Hoogenboom (2015). Water and nitrogen productivity of maize under semiarid environments. Crop Sci. 55 (1): 877-888

Hirniak, J. N. (2018).Evaluation of nitrogen and potassium interactions in corn. M. Sc. Thesis, Depart. Soil Sci. (Soil Fertility), Iowa State Univ. Ames, Iowa.

Jackson, N. E. (1973).Soil Chemical Analysis. Prentice Hall, Inc.; Englewood Cliffs, NJ: p. 498.

Jasar, M.; K. Khan; N. Ali; M. M. Anjum; A. Raza and M. Nauman (2019). Influence of different potash levels on spring maize hybrids. Adv. Plants Agric. Res., 9 (1): 27-33.

Jiang, W.; X. Liu; Y. Wang; Y. Zhang and W. Qi (2018).Responses to potassium application and economic optimum $\mathrm{k}$ rate of maize under different soil indigenous k supply. Sustainability, 10: 1-10. www.mdpi.com/journal/sustainability.

Jordan-Meille L. and S. Pellerin (2004). Leaf area establishment of a maize (Zea mays, L.) field crop under potassium deficiency. Plant Soil, 265: 7592

Law-Ogbomo, K. E. and J. E. Law-Ogbomo (2009).The Performance of Zea mays as Influenced by NPK Fertilizer Application Not. Sci. Biol., 1 (1): 59-62.

Mi, N.; F. Cai; Y. S. Zhang; R. P. Ji; S. J. Zhang; and Y. Wang (2018): Differential responses of maize yield to drought at vegetative and reproductive stages. Plant Soil Environ., 64 (6): 260-267.

Muhammad, L.T. (2005). Development of maize under water stress area. Dawn News, 1-4.

Niu, J.; W. Zhang; X. Chen; C. Li; F. Zhang; L. Jiang; Z. Liu; K. Xiao; M. Assaraf and P. Imas (2011). Potassium fertilization on maize under different production practices in the north China plain. Agron. J. 103 (3): 822:829.

Paschalidis, X.; Z. Ioannou; X. Mouroutoglou; A. Koriki; V. Kavvadias; P. Baruchas; I. Chouliaras and S. Sotiropoulos (2015).Effect of fertilization and irrigation on plant mass accumulation and maize production (Zea mays, L.). Int. J. Waste Resources, 5 (1): 1-4.
Pettigrew, W. T. (2008). Review of potassium influences on yield and quality production for maize, wheat, soybean and cotton. Physiol. Plant., 133: 670-681.

Rimski-Korsakov, H.; G. Rubio and R. S. Lavado (2009).Effect of water stress in maize crop production and nitrogen fertilizer rate. J. Plant Nutr., 32 (3): 565-578.

Rowell, D. L. (1995).Soil science methods and applications.Library of Congress Cataloging Publication Data. New York. NY 10158. USA.

Sapkota, A.; R. K. Shrestha and D. Chalise (2017).Response of maize to the soil application of nitrogen and phosphorous fertilizers. J. Appl. Sci. Biotechnol., 5 (4): 537-541.

Shirazi, S. M.; M. Sholichin; M. Jameel; S. Akib and M. Azizi (2011).Effects of different irrigation regimes and nitrogenous fertilizer on yield and growth parameters of maize. Int. J. Phys. Sci., 6 (4): 677-683.

Tabatabaii, E. S.; M. Yarnia; M. B. Khorshidi and E. Farajzadeh (2011).Effect of potassium fertilizer on corn yield (Jeta cv.) under drought stress condition. American-Eurasian J. Agric. \& Environ. Sci., 10 (2): 257-263.

Ul-Allah, S.; M. Ijaz; A. Nawaz; A. Sattar; A. Sher; M. Naeem; U. Shahzad; U. Farooq; F. Nawaz and K. Mahmood (2020). Potassium application improves grain yield and alleviates drought susceptibility in diverse maize hybrids. Plants, 9 (75): 1-11. http://www.mdpi.com/22237747/9/1/75/s1.

Wang, Y; Y. Huang; W. Fu; W. Guo; N. Ren; Y. Zhao and Y. Ye (2020). Efficient physiological and nutrient use efficiency responses of maize leaves to drought stress under different field nitrogen conditions. Agronomy, 10, 523: 1-14. WWW. mdpi.com/journal/agronomy.

Waraich, E. A.; A. Rashid and A.My (2011).Role of mineral nutrition in alleviation of drought stress in plants. Aus. J. Crop Sci., 5 (6): 764-777.

Wiebold, B. and P. Scharf (2006). Potassium deficiency symptoms in drought stressed crops, plant stress resistance and the impact of potassium application south china. Agron. J., 98: 1354-1359.

Zingore, S. (2011). Maize productivity and response to fertilizer use as affected by soil fertility variability, manure application, and cropping system. Better Crops, 95 (1): 4 - 6. 


\title{
تأثير الإجهاد المائي، السماد الأزوتي و البوتاسي على إنتاجية الذرة الثامية
}

\author{
السعيد محمد محمود الجدوي ـ هارون محمد موسى النجارـ ناصر خميس بركات الجيزاوي ـ هيثم سيد عبدالباسط منصور

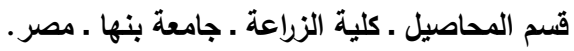

أجريت تجربتان حقليتان في مزرعة مركز البحوث و التجارب الزراعية بكلية الزراعة بمشتهر جامعة بنها (مركز طوخ ـ محافظة القليوبية ـ

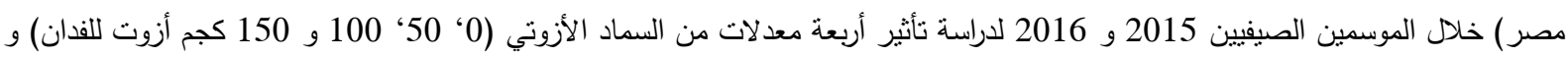

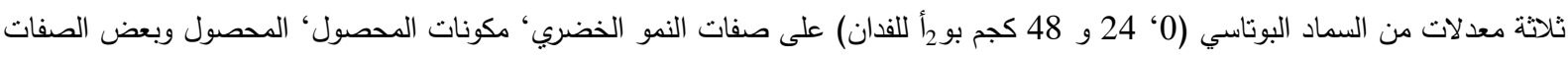

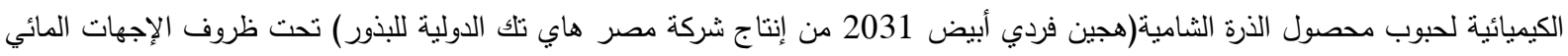

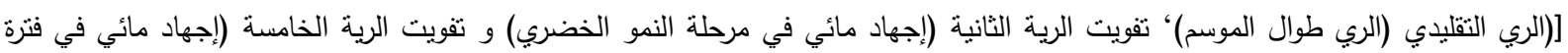

إمتلاء الحبوب)].و من خلال التحليل التجميعي لموسمي الدراسة يمكن تلخيص أهم النتائج فيما يلي:.

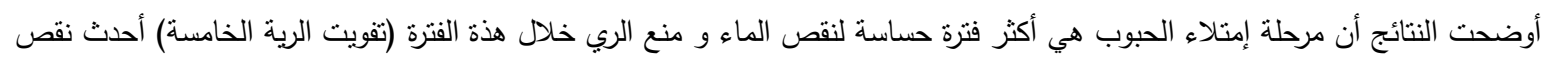

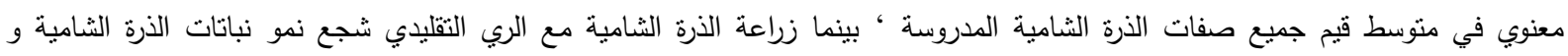

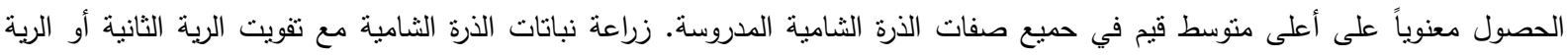

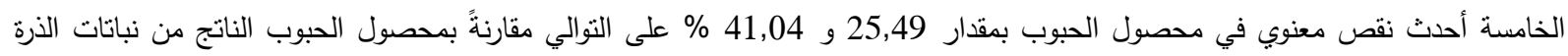
الثامية تحث الري التقليدي. زراعة الذرة الثامية مع التسميد الأزوتي بمعدل 150 كجم نيتروجين/فدان أحدث زيادة معنوية في منوسط قيم معظم صفات الذرة الثامية

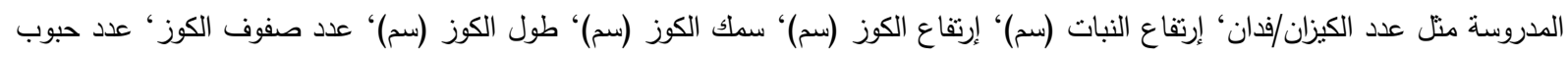

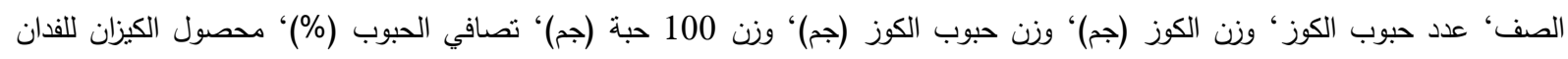

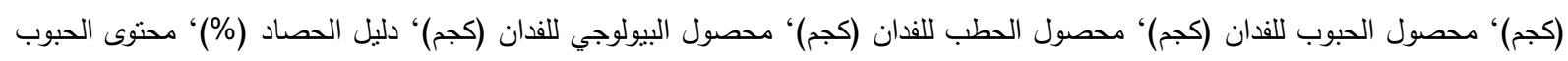

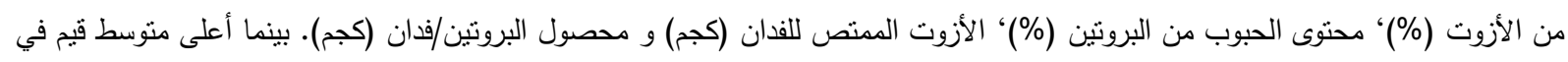

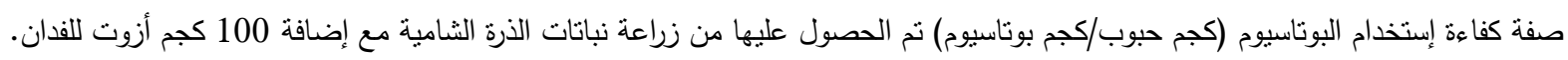

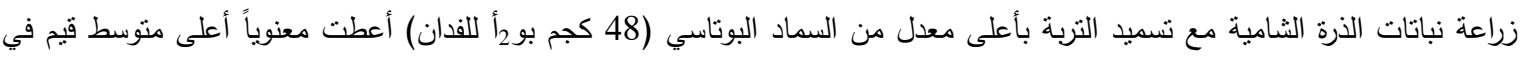

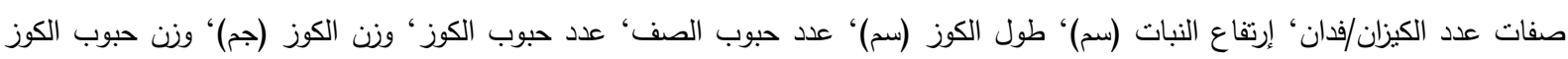
(جم)' وزن 100 حبة (جم)' تصافي الحبوب (\%)'، محصول الكيزان للفدان (كجم)' محصول الحبوب للفدان (كجم)' محصول الحطب للفدان (كجم)" محصول البيولوجي للفدان (كجم)' دليل الحصاد (\%)؛ 'محتوى الحبوب من البوتاسيوم (\%)؛ الأزوت الممتص للفدان (كجم) و محصول البروتين/فدان (كجم). بينما أعلى متوسط قيم في صفة كفاءة إستخدام البوتاسيوم (كجم حبوب/كجم بوناسيوم) تم الحصول عليها من زراعة نباتات الذرة الثامية مع إضافة 24 كجم بو 2أ للفدان. التفاعلات من الدرجة الأولى (الري التقليدي × 150 كجم أزوت للفدان)، (الري التقليدي × 48 كجم بودأ للفدان) و (150 كجم أزوت للفدان × 48 كجم بوأ للفدان) و التفاعل من الدرجة الثانية (الري التقليدي × 150 كجم أزوت ×48 كجم بوأ للفدان) حققت معنويا أعلى محصول حبوب مقارنة بالتفاعلات الأخري. توصي النتائج بأن زراعة الذرة الثامية هجين فردي أبيض الألات 2031 تحت الري النقليدي (الري طول الموسم) مع التسميد بـ 150 كجم أزوت + 48 كجم بوأ للفدان حيث عظمت إنتاجية محصول الحبوب بوحدة المساحة. 